\title{
Effects of Dietary Carbohydrate Levels on the Growth and Glucose Metabolism of Juvenile Swimming Crab, Portunus trituberculatus
}

\author{
Xiangsheng Zhang, Min Jin ${ }^{\mathbb{D}}$, Jiaxiang Luo, Shichao Xie, Chen Guo, Tingting Zhu, \\ Xiaoying Hu, Ye Yuan, and Qicun Zhou
}

Laboratory of Fish and Shellish Nutrition, School of Marine Sciences, Ningbo University, Ningbo 315211, China

Correspondence should be addressed to Min Jin; jinmin@nbu.edu.cn and Qicun Zhou; zhouqicun@nbu.edu.cn

Received 8 October 2021; Accepted 23 November 2021; Published 1 February 2022

Academic Editor: Liqiao Chen

Copyright (c) 2022 Xiangsheng Zhang et al. This is an open access article distributed under the Creative Commons Attribution License, which permits unrestricted use, distribution, and reproduction in any medium, provided the original work is properly cited.

\begin{abstract}
This experiment was conducted to evaluate the effects of different carbohydrate levels on the growth performance, glycogen accumulation in tissue, enzyme activities, and expression levels of genes related to hepatopancreatic glucose and lipid metabolism and insulin signaling pathway in swimming crab, Portunus trituberculatus for 8 weeks. The results indicated that crabs fed with the $60.0 \mathrm{~g} \mathrm{~kg}^{-1}$ carbohydrate diet exhibited the highest final body weight (FBW), percent weight gain (PWG), and specific growth rate (SGR) among all treatments. FBW, PWG, and SGR significantly decreased when dietary carbohydrate levels exceeded $240.0 \mathrm{~g} \mathrm{~kg}^{-1}$. Light microscopy results showed that dietary excessive carbohydrate levels will lead to vacuole, hepatopancreatic tubule lysis, and lipid droplets in hepatopancreas. Expression levels of genes involved into glucose transport, glucose and lipid metabolism, and insulin-like metabolism in the hepatopancreas were significantly influenced by dietary carbohydrate levels. In general, the results of present study demonstrated that dietary optimal carbohydrate levels could not only improve PWG and SGR but also influence the expression of genes involved in glucose, lipid, and insulin-like metabolism. The optimal actual carbohydrate level was estimated to be $87.8-98.4 \mathrm{~g} \mathrm{~kg}^{-1}$ based on broken-line and second-order polynomial regression analysis between PWG against dietary carbohydrate levels for juvenile Portunus trituberculatus.
\end{abstract}

\section{Introduction}

As one of the three major nutrients, carbohydrates are preferentially broken down when supplying energy to the body [1]. Providing adequate amounts of digestible carbohydrates in diets formulated for aquatic species is important to avoid the use of lipids and proteins as energy sources $[1,2]$, as well as decrease ammonia excretion and water pollution [3]. In addition, appropriate levels of dietary carbohydrates can also reduce the cost of aquafeeds [4] and promote better growth performance $[5,6]$. Compared with mammals, such as mice [7], pigs [8], and lambs [9], aquatic animals cannot efficiently utilize carbohydrates [10], especially crustaceans [11]. In crustaceans, carbohydrates are not essential nutrients because they only supply energy, which a crustacean can obtain from proteins and lipids [12], while many studies have shown that about $20 \mathrm{~g} \mathrm{~kg}^{-1}$ carbohydrate level in the feed formula is the most appropriate for crustaceans [13-16]. Excessive carbohydrate intake will reduce growth rate and affect glucose and lipid metabolism, resulting in high mortality $[5,17,18]$. Thus, it is important to determine the appropriate carbohydrate level in order to reduce aquafeed costs and improve growth performance.

Carbohydrate provides the major part of energy in the diets for human and most farmed animals, and when catabolised, available polysaccharides in different forms are completely hydrolyzed into glucose and absorbed by various organs $[1,19]$. Glucose is the major product of carbohydrate digestion, although other monosaccharides, such as fructose, galactose, and xylose, may be present in small quantities [1] Glucose is usually stored in the hepatopancreas and muscles in the form of glycogen [18]. Glycogen is a rapidly mobilized 
short-term reserve fuel, which plays an important role in maintaining the stability of hemolymph glucose. Glycogen synthase (GS) is the rate-limiting enzyme for the synthesis of glycogen from glucose [20]. However, excessive glycogen and lipid accumulation in the tissues may result in poor growth, weaken immunity, and ultimately cause death of crustaceans [21-23]. When fish or crustaceans go without food for long periods, it first consumes hepatopancreatic glycogen for energy, which is hydrolyzed into glucose by glucose-6-phosphatase [18]. Since there is no glucose-6phosphatase in muscle, muscle glycogen can only be broken down into glucose through glycolysis or aerobic oxidation. Glycolysis is a series of reactions that decompose glucose into pyruvate under the action of two key enzymes, glucokinase (GK) and hexokinase (HK). Moreover, glucose-6phosphatase (G6Pase), fructose-1,6-bisphosphatase (FBPase), and phosphoenolpyruvate carboxykinase (PEPCK) are the important rate-limiting enzyme of the gluconeogenesis pathway $[24,25]$. Meanwhile glucose metabolism is closely related to lipid accumulation and synthesis, many previous studies have confirmed that high carbohydrate diets can increase lipid deposition by pentose-phosphate pathway $[6,26,27]$.

Swimming crab, Portunus trituberculatus, widely distributed in coastal seawater of China, South Korea, and Japan, has become one of the most important culture crustacean species [28]. Due to its rapid growth, delicious meat, rich nutrition, resilience to handling, and great market value and potential, swimming crab production in 2018 has reached up to 116,251 tons (China Fishery Statistical [29]). However, in traditional aquaculture, swimming crabs culture mainly depended on trash fish and shellfish, which may lead to water pollution and diseases outbreak [28, 30]. Therefore, it is necessary to develop a suitable commercial aquafeed in order to promote the healthy, environmentally friendly, and efficient modern farming of swimming crabs. So far, the studies focused on the nutritional requirements of key nutrients such as protein and lipid requirements of swimming crabs $[28,31,32]$. However, the effect of dietary carbohydrate levels on growth and the regulation of glucose digestion, absorption, transportation, and glucose anabolism and catabolism has not been studied in P. trituberculatus. Therefore, the present study is aimed at determining the optimal carbohydrate supplementation and evaluated the influence of different carbohydrate levels on the growth performance, feed utilization, glucose metabolism enzyme activity, and gene expression of key enzymes involved in glucose transport and insulin pathway in swimming crabs.

\section{Materials and Methods}

2.1. Ethics Statement. All experimental procedures were performed in strict accordance with the Standard Operation Procedures (SOPs) of the Guide for Use of Experimental Animals of Ningbo University. The experimental protocol and procedures were approved by the Institutional Animal Care and Use Committee of Ningbo University.

2.2. Experimental Design. Six diets were designed to be 0.0 , $60.0,120.0,180.0,240.0$, and $300.0 \mathrm{~g} \mathrm{~kg}^{-1}$ carbohydrate levels, and the actual contents were 29.5, 83.9, 147.7, 200.7, 262.8, and $321.5 \mathrm{~g} \mathrm{~kg}^{-1}$, respectively. Corn starch was proved to be the best carbohydrate source through another experiment (unpublished) and it was used as the carbohydrate source of this experimental diet (Table 1). All ingredients were ground into fine powder by ultrafine grinder. The microcomponents, such as vitamin mixture, mineral mixture, sodium alginate, and various oil sources, were mixed using the progressive enlargement method firstly (premix the raw materials with less than $100 \mathrm{~g}$ addition amount and then mix with the large amount of raw materials). Extruding the plasmids of the raw materials through the extruder and the granulator, respectively, two sizes of pellets (diameters $2 \mathrm{~mm}$ and $4 \mathrm{~mm}$ ) are produced, steamed for $30 \mathrm{~min}$ at $90^{\circ} \mathrm{C}$, and finally air-dried to approximately $100.0 \mathrm{~g} \mathrm{~kg}^{-1}$ moisture. The dried diets were sealed in vacuum-packed bags and stored at $-20^{\circ} \mathrm{C}$ until used.

2.3. Feeding Trial and Experimental Conditions. Swimming crab juveniles were purchased from a local crab breeding farm (Xiangshan, Ningbo, China). Feeding trial was conducted in Ningbo Xiangshan Harbor Aquatic Seed Co. Ltd. Prior to the start of the feeding trial, healthy and the similar-sized swimming crab juveniles were acclimated for 7 days and fed with a commercial diet $\left(450 \mathrm{~g} \mathrm{~kg}^{-1}\right.$ dietary protein and $80 \mathrm{~g} \mathrm{~kg}^{-1}$ crude lipid, Ningbo Tech-Bank Feed Co. Ltd., Ningbo, China). The initial average weight of 180 swimming crab juveniles was $7.87 \pm 0.03 \mathrm{~g}$ and randomly sorted into 180 individual rectangle plastic baskets $(35 \times$ $30 \times 35 \mathrm{~cm})$ in three cement pools $(6.8 \times 3.8 \times 1.7 \mathrm{~m})$. There was a partition in the middle of each basket, which divided the basket into two equal sections. One section is filled with sand $1 / 2$ and used as a habitat. The other area is empty which is used as a feeding area. Each diet was randomly assigned to three replicates, and each replicate had 10 plastic baskets that supported with a foam frame so that it does not sink to the bottom. All plastic baskets were lined up in the cement pool and fixed them with a nylon rope to prevent the plastic baskets from floating to the center of the pool. All of the crabs were fed twice daily at 7:00 and 17:30, respectively, and feeding about $1 / 5$ of the total amount in the morning and $4 / 5$ of the total amount in the evening. Newly molted crabs were not fed for one day. Feces, uneaten feed, and crab shells were removed, and about $30 \%$ of seawater in the cement pool was daily exchanged to maintain seawater quality. Furthermore, the amounts of uneaten complete pellets (crushed residue feeds are few, which can basically be not counted) and dead crabs were recorded, weighed, and calculated. In order to continuously supply oxygen, 12 air pipes connected to air stones were placed in the cement pool for continuous aeration. During the experimental period, the temperature of the cement pool was 27$30.5^{\circ} \mathrm{C}$, the salinity was $22.5-25.5 \mathrm{gl}^{-1}$, $\mathrm{pH}$ was $7.3-8.0$, and ammonia nitrogen was lower than $0.05 \mathrm{mg} \mathrm{L}^{-1}$.

2.4. Sample Collection. At the end of the trial, the survival, final body weight (FBW), percent weight gain (PWG), specific growth rate (SGR), and molting ratio (MR) were measured. Hemolymph samples from six crabs in each 
TABLE 1: Ingredients and proximate composition of the experimental diets $\left(\mathrm{g} \mathrm{kg}^{-1}\right.$, dry matter).

\begin{tabular}{|c|c|c|c|c|c|c|}
\hline \multirow{2}{*}{ Ingredients $\left(\mathrm{g} \mathrm{kg}^{-1}\right)$} & \multicolumn{6}{|c|}{ Dietary carbohydrate levels $\left(\mathrm{g} \mathrm{kg}^{-1}\right)$} \\
\hline & 0 & 60 & 120 & 180 & 240 & 300 \\
\hline Fish meal $^{\mathrm{a}}$ & 280.0 & 280.0 & 280.0 & 280.0 & 280.0 & 280.0 \\
\hline Shrimp meal ${ }^{\mathrm{a}}$ & 30.0 & 30.0 & 30.0 & 30.0 & 30.0 & 30.0 \\
\hline Soybean meal ${ }^{\mathrm{a}}$ & 150.0 & 150.0 & 150.0 & 150.0 & 150.0 & 150.0 \\
\hline Soy protein concentrate ${ }^{a}$ & 130.0 & 130.0 & 130.0 & 130.0 & 130.0 & 130.0 \\
\hline Poultry byproduct meal ${ }^{\mathrm{a}}$ & 20.0 & 20.0 & 20.0 & 20.0 & 20.0 & 20.0 \\
\hline Corn starch & 0.0 & 60.0 & 120.0 & 180.0 & 240.0 & 300.0 \\
\hline Fish oil ${ }^{\mathrm{a}}$ & 15.0 & 15.0 & 15.0 & 15.0 & 15.0 & 15.0 \\
\hline Soybean oil ${ }^{\mathrm{a}}$ & 15.0 & 15.0 & 15.0 & 15.0 & 15.0 & 15.0 \\
\hline Soy lecithin ${ }^{\mathrm{a}}$ & 20.0 & 20.0 & 20.0 & 20.0 & 20.0 & 20.0 \\
\hline Choline chloride & 5.0 & 5.0 & 5.0 & 5.0 & 5.0 & 5.0 \\
\hline $\mathrm{Ca}\left(\mathrm{H}_{2} \mathrm{PO}_{4}\right)_{2}$ & 10.0 & 10.0 & 10.0 & 10.0 & 10.0 & 10.0 \\
\hline Vitamin mixture $^{\mathrm{a}}$ & 5.0 & 5.0 & 5.0 & 5.0 & 5.0 & 5.0 \\
\hline Mineral mixture $^{\mathrm{a}}$ & 10.0 & 10.0 & 10.0 & 10.0 & 10.0 & 10.0 \\
\hline Sodium alginate & 10.0 & 10.0 & 10.0 & 10.0 & 10.0 & 10.0 \\
\hline Cellulose & 300.0 & 240.0 & 180.0 & 120.0 & 60.0 & 0.0 \\
\hline \multicolumn{7}{|c|}{ Proximate composition $\left(\mathrm{g} \mathrm{kg}^{-1}\right)$} \\
\hline Moisture & 97.4 & 92.1 & 85.7 & 93.5 & 98.8 & 92.0 \\
\hline Crude protein & 428.4 & 428.0 & 428.1 & 429.3 & 421.9 & 422.6 \\
\hline Crude lipid & 79.8 & 78.8 & 80.4 & 81.0 & 80.8 & 80.1 \\
\hline Ash & 62.3 & 68.7 & 67.6 & 67.0 & 67.4 & 68.9 \\
\hline Crude fiber & 306.4 & 249.3 & 190.5 & 127.5 & 68.3 & 10.9 \\
\hline $\mathrm{NFE}^{\mathrm{b}}$ & 29.5 & 83.9 & 147.7 & 200.7 & 262.8 & 321.5 \\
\hline Gross energy $\left(\mathrm{kJ} \mathrm{g}^{-1}\right)^{\mathrm{c}}$ & 13.62 & 14.62 & 15.82 & 16.82 & 17.67 & 18.82 \\
\hline
\end{tabular}

${ }^{a}$ All raw materials are purchased from Tianbang Co., Ltd. ${ }^{b}$ Nitrogen - free extract $=100 \%-($ moisture $\%+$ crude protein $\%+$ crude lipid $\%+$ ash $\%+$ crude fiber\% $).{ }^{c}$ Energy $=($ crude protein $\% \times 23.6+$ crude lipid $\% \times 39.50+$ starch $\% \times 17.2) / 100$.

replicate were taken from the pericardial cavity using $2 \mathrm{ml}$ syringes, sorted into $1.5 \mathrm{ml}$ Eppendorf tubes at $4^{\circ} \mathrm{C}$ overnight, and centrifuged for $10 \mathrm{~min}$ at $3500 \mathrm{rpm}$ (Eppendorf centrifuge 5810R, Germany). Then, the supernatant was collected and stored at $-80^{\circ} \mathrm{C}$ until analysis of serum biochemical index and carbohydrate metabolic enzyme activity. The hepatopancreas from six same crabs after being taken blood were collected into two $2 \mathrm{ml}$ Eppendorf tubes and four $1.5 \mathrm{ml}$ Eppendorf tubes immediately, $2 \mathrm{ml}$ Eppendorf tubes were frozen in liquid nitrogen and stored at $-20^{\circ} \mathrm{C}$ until analysis of composition, and the $1.5 \mathrm{ml}$ Eppendorf tubes were stored at $-80^{\circ} \mathrm{C}$ for the gene expression, content of glycogen, and ATP. The muscles from six same crabs were collected for composition analysis and content of glycogen.

2.5. Chemical Analysis. The proximate compositions in experimental diets, whole body, hepatopancreas, and muscle were determined according to AOAC [33]. The total protein, glucose, and triglyceride contents in hemolymph were assayed using an automatic biochemistry analyzer (Vitalab Selectra Junior Pros, Netherlands). The contents of lactic acid and pyruvate were determined using assay kits (Nanjing Jiancheng Bioengineering Institute, China). And the concentrations of insulin-like and hyperglycemic hormone were measured using assay kits (Shanghai Qiaodu Biological Technology Co., Ltd., China).

Briefly, moisture content was determined by drying the samples to a constant weight at $105^{\circ} \mathrm{C}$. Crude protein $(\mathrm{N} \times 6.25)$ was determined via the Dumas combustion methods with a protein analyzer (FP-528, Leco, USA). Crude lipid was determined by the ether extraction method using Soxtec System HT (Soxtec System HT6, Tecator, Sweden), and ash content was determined using a muffle furnace at $550^{\circ} \mathrm{C}$ for $8 \mathrm{~h}$. Lactic acid, pyruvate, insulin-like, and hyperglycemic hormone were determined spectrophotometrically.

Lactic acid and pyruvate were determined by colorimetry. Lactic acid uses $\mathrm{NAD}^{+}$as the hydrogen acceptor. Lactate dehydrogenase promotes the dehydrogenation of lactic acid to produce pyruvate, which converts $\mathrm{NDH}^{+}$into $\mathrm{NADH}$. Among them, PMS transfers hydrogen to reduce NBT to a purple color. The absorbance of the color is at $530 \mathrm{~nm}$, and the content of lactic acid has a linear relationship. Pyruvate is a product of anaerobic metabolism of sugar and is usually determined together with lactic acid.

Insulin-like peptide was determined by used doubleantibody one-step sandwich enzyme-linked immunosorbent assay (ELISA). Add the specimen, standard, and HRPlabeled detection antibody to the precoated insulin-like 
peptide antibody-coated microwells, incubate, and wash thoroughly. The color is developed with the substrate TMB. TMB is converted into blue under the catalysis of peroxidase and into the final yellow under the action of acid. The intensity of the color is positively correlated with the glucagon (GC) in the sample. Measure the absorbance (OD value) with a microplate reader at a wavelength of $450 \mathrm{~nm}$ to calculate the sample concentration. Hyperglycemia hormones were determined using the same method as insulinlike peptides and used hyperglycemic hormone antibodies.

\subsection{Tissue Glycogen and Enzyme Activity Parameter Assays.} The hepatopancreas samples need to be homogenized in ice bath with 9 volumes $(w / v)$ of normal saline and then centrifugated at $3000 \mathrm{rpm}$ for $10 \mathrm{~min}$ at $4^{\circ} \mathrm{C}$ (Eppendorf centrifuge 5810R, Germany), and serum can be directly measured according to the instructions. The alpha-amylase content in hepatopancreas and the activities of pyruvate kinase, lactate dehydrogenase, and hexokinase in serum were analyzed using assay kits (Nanjing Jiancheng Bioengineering Institute, China). The contents of glycogen in muscles and hepatopancreas and ATP in hepatopancreas also use assay kits (Nanjing Jiancheng Bioengineering Institute, China) to determine according to corresponding protocols.

Alpha-amylase, pyruvate kinase, and lactate dehydrogenase were also determined by colorimetry. Amylase can be hydrolyzed into glucose, maltose, and dextrin by alphaamylase. When the substrate concentration is known and excessive, iodine solution is added to combine with unhydrolyzed starch to form a blue complex, which can be calculated based on the shade of blue starch content. Pyruvate can be catalyzed into PEP by pyruvate kinase in the presence of ADP. Pyruvate can be catalyzed into lactic acid by lactate dehydrogenase, which reacts with 2,4-dinitrophenylhydrazine, which is brown-red in alkaline solution.

Hexokinase was determined by the UV method. Under the catalysis of hexokinase, glucose 6-phosphate is synthesized from glucose, and glucose 6-phosphate is dehydrogenated to NADPH under the action of glucose 6-phosphate dehydrogenase. NADPH has a characteristic absorption peak at $340 \mathrm{~nm}$.

Glycogen and ATP were determined by colorimetry. Under the action of concentrated sulfuric acid, glycogen can generate aldehyde derivatives and then react with anthrone to generate blue compounds, which are colorimetrically compared with the standard glucose solution treated by the same method. ATP and creatine are catalyzed by creatine kinase to generate creatine phosphate, which is determined by the phosphomolybdic acid colorimetric method.

2.7. Tissue Section and Observation. All hepatopancreatic slice samples were taken near from the heart of the crabs. Determinations of the hepatopancreas histology were processed as described by Liu et al. [34] with some modifications. Briefly, hepatopancreas tissues were immediately immersed in $4 \%$ tissue fixative (paraformaldehyde), then fixed (at least $24 \mathrm{~h}$ ), trimmed, and dehydrated in ethanol. Subsequently, they were embedded in paraffin and cut into $4 \mu \mathrm{m}$ sections and finally stained with hematoxylin and eosin (H\&E); the images were obtained under a microscope at 400 times (Nikon Eclipse CI, Tokyo, Japan). Further measures, such as area and number of hepatopancreatic $B$ cell and number of hepatopancreatic $\mathrm{R}$ cell, were calculated by ImageJ. In each of these indicators, 10 measurements were acquired $(n=30)$ per tissue sample.

2.8. RNA Extraction and Real-Time Quantitative PCR. RNA extraction and PCR analysis completely referred to Yuan et al. [35]. RNA was extracted and reverse transcribed by TRIzol Reagent and HiScript RT SuperMix Reagent kit (Vazyme, China), respectively. All specific primers and housekeeping genes were designed by Primer Premier 5.0, synthesized by BGI (Beijing Genomics Research Institute, Shenzhen, China), and verified to be usable (including those cited from other literature) (Table 2). In the present study, the expression of genes related to hepatopancreatic glucose and lipid metabolism key enzymes and insulin signaling pathway in swimming crab juveniles was studied. All gene expression data were expressed relative to the expression of the $0.0 \mathrm{~g} \mathrm{~kg}^{-1}$ carbohydrate level treatment. The fluorescence data were normalized to $\beta$-actin and quantified by the $2^{-\Delta \Delta \mathrm{Ct}}$ method [36].

2.9. Calculations and Statistical Analysis. The parameters were calculated as follows: PWG $(\%)=100 \times$ (final body weight - initial body weight)/initial body weight, SGR (\%da $\left.\mathrm{y}^{-1}\right)=100 \times \operatorname{Ln}($ final body weight/initial body weight $) /$ days, Survival $(\%)=100 \times$ final crab number/initial crab number, and $\mathrm{MI}$ (day) = total days spent molting/total molting times.

Data are presented as the means and standard errors of three replicates $(n=3)$ and analyzed by one-way ANOVA followed by Tukey's multiple-range test. All statistical analyses were conducted using SPSS 16.0 for Windows.

For heat map visualisation analysis, all data were homogenized and performed using the online programme Image GP (http://www.ehbio.com/ImageGP/index.php/).

\section{Results}

3.1. Growth Performance, Survival, and Molting Ratio. The effects of different dietary carbohydrate levels on growth performance, survival, and molting ratio of swimming crab juveniles are presented in Table 3. Final body weight (FBW), percent weight gain (PWG), and specific growth rate (SGR) are significantly influenced by dietary carbohydrate levels $(P<0.05)$. Crabs fed with the $60.0 \mathrm{~g} \mathrm{~kg}^{-1}$ carbohydrate level had the highest FBW, PWG, and SGR and that significantly decreased with dietary carbohydrate levels increasing from 180.0 to $300.0 \mathrm{~g} \mathrm{~kg}^{-1}$. Based on broken-line and secondorder polynomial regression analysis between PWG against dietary carbohydrate levels, the optimal actual carbohydrate levels were estimated to be $87.8-98.4 \mathrm{~g} \mathrm{~kg}^{-1}$ for juvenile swimming crab (Figure 1). The molting interval (MI) of crabs fed with the 240.0 and $300.0 \mathrm{~g} \mathrm{~kg}^{-1}$ carbohydrate levels was significantly longer than the 240.0 and $300.0 \mathrm{~g} \mathrm{~kg}^{-1}$ carbohydrate levels $(P<0.05)$. Survival among all treatments had no significant differences $(P>0.05)$. 
TABLE 2: Real-time PCR primer sequences for analysis of gene expression in hepatopancreas of swimming crab.

\begin{tabular}{|c|c|c|c|}
\hline \multirow{2}{*}{ Gene names } & \multicolumn{2}{|c|}{ Primers } & \multirow{2}{*}{ Access no. } \\
\hline & Forward $\left(5^{\prime}-3^{\prime}\right)$ & Reverse $\left(5^{\prime}-3^{\prime}\right)$ & \\
\hline$g k$ & AGGTGGACCAACACTCTCGC & TCCAGCAAGCCACAGGTCTC & XP_023223115 \\
\hline$p k$ & ACACCAAAGGACCCGAAATC & ATGCCGCCATTCTCTACCTC & ALK82311 \\
\hline$h k$ & TATGTGGCAGGAATCGTGTC & GGAGTCTATCAGCAATGGCG & ABO21409 \\
\hline g6pase & ATGTGGACGCTGCTCTTCTG & CACCATCCAAGTGGCATACC & ALK82315 \\
\hline fbpase & CAGAAGAAAATCCCTCACGC & CСACATACTTCСССТGACGA & AMJ52089 \\
\hline pepck & CGAGCCGCTACCCAAATA & CGAAGTCGTCCTCGTTGA & AAL78163 \\
\hline glut1 & TGGTGCGGAACTCCAATCTA & GAAGCCTATGCCGACAATGA & AIT97017 \\
\hline glut2 & CGATGGGAGCCTTGAGTTTT & ACAGGATTCCAACCACGACC & ALG65274 \\
\hline$g s k$ & AGGTGCTCCAGGATAAACGG & ACACACCCAGCGAGTGAATG & ASW35107 \\
\hline foxo & CATAAGTTCTCGCCAGCCTC & TAACCTTCAGGACACGGGAG & XP_023216972 \\
\hline$i g f 1 r$ & CACTCACCAGGAGCCCATCTA & TCAGAGAGTTTCACAACCCGC & XP_023716772 \\
\hline pi3k & AGCCACCACTCGCTGAACA & GGGATGGGACTCTGCTGAAG & ADE44090 \\
\hline fas & CTTCAATACCCACCAAACC & CCTCAATGATGCCAGACAC & Sun et al. [72] \\
\hline$a c c$ & TCTCAGGGCAACCTTACGCT & CGGGAGGCAGTAACCATTCA & Sun et al. [72] \\
\hline srebp1 & GTGATGTGTGCCTTGCGAGT & CCAGGGTTCACCAGTGTAGT & Sun et al. [72] \\
\hline $6 p g d$ & GGGTGGAACCTCAACTATGG & CGATAGCCATCATAGAAAGCC & Sun et al. [72] \\
\hline g6pd & TGAAAAGGTGAAGGTGCTGA & CGGTGGAGTCATCAAGGTAAC & Sun et al. [72] \\
\hline$c p t 1$ & GCTTGCCTACTACCGACAC & CCTTGGACATCTTACTGCTC & Sun et al. [72] \\
\hline$c p t 2$ & TGGGACAAGGTTTTGATAGGC & TGGAGATGATGATGTGGTTGA & Sun et al. [72] \\
\hline tor & TGTGGACATAGGGCAAACTG & GACCGCTTCACCAAATCATC & Zhan et al. [18] \\
\hline$s 6 k 1$ & CGCCCCTCAGATTTCCAGT & TCTCAGCCTTTGTGTGCG & Zhan et al. [18] \\
\hline$a k t$ & GGACTACGAGGCACCAAGAA & TGGACCACTTCATCACGCTC & Zhan et al. [18] \\
\hline$\beta$-actin & GAAGTAGCCGCCCTGGTTGT & GAATACCTCGCTTGCTCTGC & Sun et al. [72] \\
\hline
\end{tabular}

TABle 3: Growth performance, feed utilization, and molting rate of Portunus trituberculatus fed with different carbohydrate levels for 8 weeks.

\begin{tabular}{|c|c|c|c|c|c|c|}
\hline \multirow{2}{*}{ Parameters } & \multicolumn{6}{|c|}{ Dietary carbohydrate levels $\left(\mathrm{g} \mathrm{kg}^{-1}\right)$} \\
\hline & 0 & 60 & 120 & 180 & 240 & 300 \\
\hline Initial body weight (g) & $7.86 \pm 0.03$ & $7.92 \pm 0.04$ & $7.85 \pm 0.05$ & $7.87 \pm 0.01$ & $7.84 \pm 0.03$ & $7.87 \pm 0.02$ \\
\hline Final body weight (g) & $69.38 \pm 0.69^{\mathrm{bc}}$ & $74.13 \pm 2.00^{\mathrm{c}}$ & $68.35 \pm 2.87^{\mathrm{bc}}$ & $70.47 \pm 3.47^{\mathrm{bc}}$ & $63.00 \pm 3.94^{\mathrm{ab}}$ & $58.31 \pm 1.41^{\mathrm{a}}$ \\
\hline Percent weight gain (\%) & $782.45 \pm 11.76^{\mathrm{bc}}$ & $836.68 \pm 29.34^{\mathrm{c}}$ & $771.39 \pm 40.25^{\mathrm{bc}}$ & $795.11 \pm 44.81^{\mathrm{bc}}$ & $703.16 \pm 50.00^{\mathrm{ab}}$ & $640.65 \pm 19.64^{\mathrm{a}}$ \\
\hline Specific growth rate $\left(\%\right.$ day $\left.^{-1}\right)$ & $3.76 \pm 0.02^{\mathrm{bc}}$ & $3.86 \pm 0.05^{\mathrm{c}}$ & $3.73 \pm 0.08^{\mathrm{bc}}$ & $3.77 \pm 0.09^{\mathrm{bc}}$ & $3.58 \pm 0.10^{\mathrm{ab}}$ & $3.45 \pm 0.05^{\mathrm{a}}$ \\
\hline Survival (\%) & $90.00 \pm 0.00$ & $76.67 \pm 6.67$ & $76.67 \pm 3.33$ & $73.33 \pm 6.67$ & $83.33 \pm 3.33$ & $76.67 \pm 3.33$ \\
\hline Molting interval (day) & $13.99 \pm 0.05^{\mathrm{a}}$ & $14.94 \pm 0.19^{\mathrm{a}}$ & $15.28 \pm 0.20^{\mathrm{ab}}$ & $15.30 \pm 0.41^{\mathrm{ab}}$ & $16.75 \pm 0.55^{\mathrm{bc}}$ & $16.98 \pm 0.26^{\mathrm{c}}$ \\
\hline
\end{tabular}

Data are reported as the mean \pm SEM of three replicates $(n=3)$. Means in each line with different superscript letters are significantly different $(P<0.05)$.

3.2. Proximate Composition in Whole Body, Hepatopancreas, and Muscle. Moisture, lipid, and protein contents in hepatopancreas and muscles as well as moisture and protein contents in the whole body had no significant differences (Table 4). However, crabs fed with the $0.0 \mathrm{~g} \mathrm{~kg}^{-1}$ carbohydrate level had lower lipid content in whole body than those fed with the other diets $(P<0.05)$. The ash content in whole body was significantly influenced by dietary carbohydrate levels $(P<0.05)$.

3.3. Hemolymph Biochemistry Parameters. The hemolymph biochemistry parameters of crabs fed with different carbohydrate levels are presented in Table 5. Crabs fed with the
$0.0 \mathrm{~g} \mathrm{~kg}^{-1}$ carbohydrate level exhibited the lowest glucose content $(P<0.05)$. Crabs fed with the 240.0 and $300.0 \mathrm{~g} \mathrm{~kg}^{-}$ ${ }^{1}$ carbohydrate levels had lower lactic acid content in serum than those fed with the other diets $(P<0.05)$. The hyperglycemic hormone content in serum significantly increased with dietary carbohydrate levels increasing from 0.0 to $120.0 \mathrm{~g} \mathrm{~kg}^{-1}$ and then significantly decreased with further increase of dietary carbohydrate levels $(P<0.05)$. However, the total protein, triglyceride, and insulin-like contents had no significant differences among all diets $(P>0.05)$.

3.4. Glycogen, ATP, and Enzyme Activities in Hepatopancreas. As shown in Figure 2, crabs fed with the 240.0 and $300.0 \mathrm{~g} \mathrm{~kg}^{-1}$ 


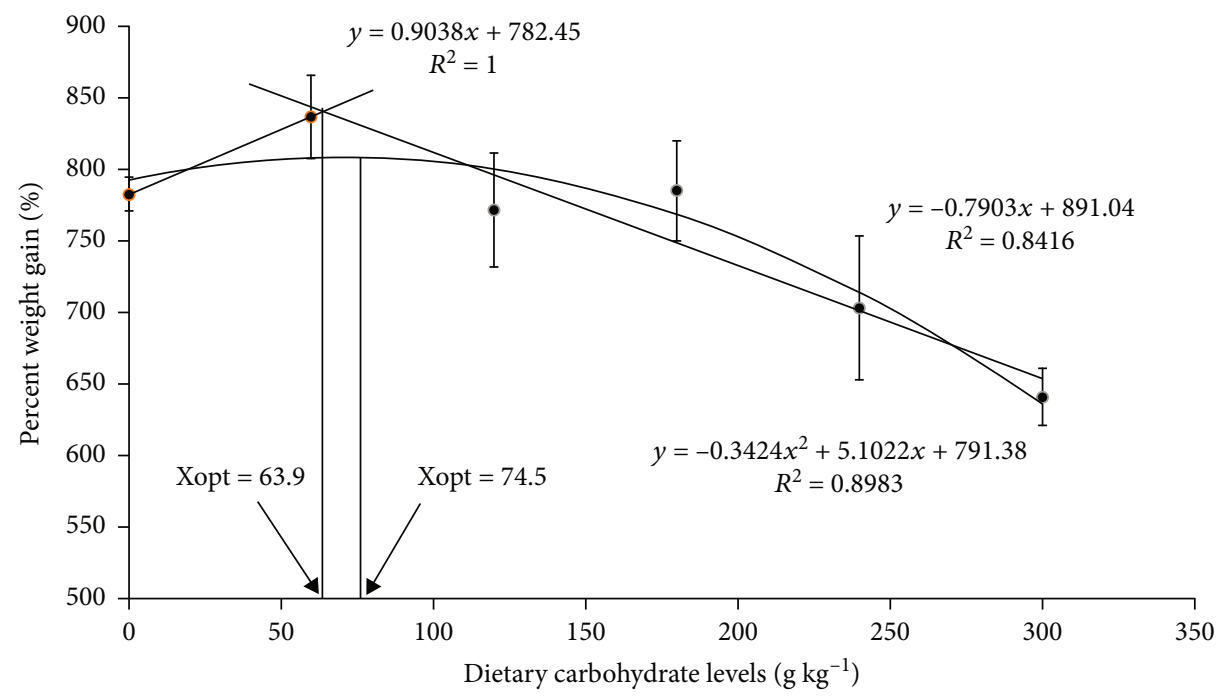

FIGURE 1: Relationship of percent weight gain (PWG) and dietary carbohydrate levels of Portunus trituberculatus based on broken-line and second-order polynomial regression analysis, where Xopt represents the optimal dietary carbohydrate level for the maximum PWG.

TABle 4: Proximate composition in whole body, muscle, and hepatopancreas of Portunus trituberculatus fed with different carbohydrate levels for 8 weeks $\left(\mathrm{g} \mathrm{kg}^{-1}\right.$, wet weight).

\begin{tabular}{|c|c|c|c|c|c|c|}
\hline \multirow{2}{*}{ Proximate composition $\left(\mathrm{g} \mathrm{kg}^{-1}\right)$} & \multicolumn{6}{|c|}{ Dietary carbohydrate levels $\left(\mathrm{g} \mathrm{kg}^{-1}\right)$} \\
\hline & 0 & 60 & 120 & 180 & 240 & 300 \\
\hline \multicolumn{7}{|l|}{ Whole body } \\
\hline Moisture & $75.11 \pm 0.03$ & $72.21 \pm 0.03$ & $72.48 \pm 0.01$ & $75.43 \pm 0.00$ & $72.40 \pm 0.01$ & $75.32 \pm 0.03$ \\
\hline Protein & $11.46 \pm 0.27$ & $11.59 \pm 0.12$ & $12.27 \pm 0.23$ & $12.58 \pm 0.18$ & $11.92 \pm 0.14$ & $11.44 \pm 0.11$ \\
\hline Lipid & $1.38 \pm 0.08^{\mathrm{a}}$ & $2.28 \pm 0.14^{\mathrm{b}}$ & $1.95 \pm 0.06^{\mathrm{b}}$ & $1.95 \pm 0.16^{\mathrm{b}}$ & $2.08 \pm 0.10^{\mathrm{b}}$ & $1.89 \pm 0.19^{\mathrm{b}}$ \\
\hline Ash & $9.19 \pm 0.13^{\mathrm{a}}$ & $10.00 \pm 0.14^{\mathrm{b}}$ & $10.17 \pm 0.08^{\mathrm{b}}$ & $10.14 \pm 0.13^{\mathrm{b}}$ & $9.16 \pm 0.21^{\mathrm{a}}$ & $9.14 \pm 0.24^{\mathrm{a}}$ \\
\hline \multicolumn{7}{|l|}{ Hepatopancreas } \\
\hline Moisture & $72.68 \pm 1.65$ & $72.74 \pm 1.25$ & $75.44 \pm 1.24$ & $72.86 \pm 1.47$ & $72.99 \pm 0.62$ & $71.44 \pm 0.98$ \\
\hline Protein & $11.58 \pm 0.65$ & $11.42 \pm 0.27$ & $11.23 \pm 0.45$ & $11.62 \pm 0.57$ & $10.94 \pm 0.20$ & $10.91 \pm 0.21$ \\
\hline Lipid & $12.26 \pm 0.43$ & $12.28 \pm 0.26$ & $11.43 \pm 0.12$ & $11.71 \pm 0.48$ & $12.65 \pm 0.50$ & $13.05 \pm 0.63$ \\
\hline \multicolumn{7}{|l|}{ Muscle } \\
\hline Moisture & $79.59 \pm 0.19$ & $79.59 \pm 0.27$ & $79.58 \pm 0.88$ & $79.86 \pm 0.14$ & $80.14 \pm 0.19$ & $80.15 \pm 0.40$ \\
\hline Protein & $17.57 \pm 0.17$ & $17.50 \pm 0.16$ & $17.45 \pm 0.12$ & $17.15 \pm 0.16$ & $16.99 \pm 0.41$ & $17.22 \pm 0.02$ \\
\hline Lipid & $0.99 \pm 0.04$ & $1.04 \pm 0.14$ & $0.89 \pm 0.08$ & $1.12 \pm 0.11$ & $1.03 \pm 0.12$ & $1.02 \pm 0.03$ \\
\hline
\end{tabular}

Data are presented as the means \pm SEM of three replicates $(n=3)$. Means in each line with different superscript letters are significantly different $(P<0.05)$.

carbohydrate diets had lower alpha-amylase activity in hepatopancreas than those fed with the low carbohydrate level diets $(P<0.05)$. The activities of pyruvate kinase, lactate dehydrogenase, and hexokinase in serum were not significantly affected by dietary carbohydrate levels $(P>0.05)$. Glycogen contents in muscle and hepatopancreas and carbohydrate were positively correlated, and crabs fed with the $300.0 \mathrm{~g} \mathrm{~kg}^{-1}$ carbohydrate diet exhibited the highest glycogen content among all treatments (Figure $3, P<0.05$ ). ATP content in hepatopancreas significantly increased with dietary carbohydrate levels increasing from 0.0 to $60.0 \mathrm{~g} \mathrm{~kg}^{-1}$ and then decreased with further increase of dietary carbohydrate levels $(P<0.05)$.
3.5. Histopathological Analysis. Figure 4 shows the hepatopancreas histology of Portunus trituberculatus in different treatments. Many complete hepatopancreatic tubules with a structural feature of epithelial cells that included R (restzellen) cell, B (blasenzellen) cell, F (fibrous) cell, hepatopancreatic tubule lumen (Lu) structure, and striated border (SB) have been observed. And, the 0.0 and $60.0 \mathrm{~g} \mathrm{~kg}^{-1}$ carbohydrate level treatments had more B cells and fewer $\mathrm{F}$ cells. The SB of the treatments with 240.0 and $300.0 \mathrm{~g} \mathrm{~kg}^{-1}$ carbohydrate levels was weakened, and the hepatopancreas tubules were severely lysed. Besides, the quantitative indicators of $\mathrm{B}$ and $\mathrm{R}$ cells are displayed that the number of $\mathrm{B}$ cell was significantly decreased as well as the areas of B cell were 
Table 5: Hemolymph metabolites of Portunus trituberculatus fed with different carbohydrate levels for 8 weeks.

\begin{tabular}{|c|c|c|c|c|c|c|}
\hline \multirow{2}{*}{ Index } & \multicolumn{6}{|c|}{ Dietary carbohydrate levels $\left(\mathrm{g} \mathrm{kg}^{-1}\right)$} \\
\hline & 0 & 60 & 120 & 180 & 240 & 300 \\
\hline Total protein $\left(\mathrm{gl}^{-1}\right)$ & $28.35 \pm 2.06$ & $30.49 \pm 0.45$ & $29.45 \pm 4.20$ & $26.51 \pm 2.31$ & $23.47 \pm 2.39$ & $22.82 \pm 3.75$ \\
\hline Glucose $\left(\mathrm{mmoll}^{-1}\right)$ & $1.66 \pm 0.02^{\mathrm{a}}$ & $2.01 \pm 0.05^{\mathrm{b}}$ & $2.02 \pm 0.12^{\mathrm{b}}$ & $2.05 \pm 0.04^{\mathrm{b}}$ & $1.88 \pm 0.09^{\mathrm{ab}}$ & $1.86 \pm 0.04^{\mathrm{ab}}$ \\
\hline Triglyceride $\left(\mathrm{mmoll}^{-1}\right)$ & $0.06 \pm 0.01$ & $0.05 \pm 0.01$ & $0.04 \pm 0.01$ & $0.05 \pm 0.01$ & $0.05 \pm 0.00$ & $0.04 \pm 0.00$ \\
\hline Lactic acid $\left(\mathrm{mmoll}^{-1}\right)$ & $3.37 \pm 0.19^{\mathrm{abc}}$ & $3.78 \pm 0.08^{\mathrm{c}}$ & $3.83 \pm 0.39^{c}$ & $3.72 \pm 0.34^{b c}$ & $2.68 \pm 0.22^{\mathrm{a}}$ & $2.82 \pm 0.35^{\mathrm{ab}}$ \\
\hline Pyruvate $\left(\mu \mathrm{mol} \mathrm{ml}{ }^{-1}\right)$ & $0.13 \pm 0.02^{\mathrm{ab}}$ & $0.11 \pm 0.01^{\mathrm{ab}}$ & $0.08 \pm 0.02^{\mathrm{a}}$ & $0.07 \pm 0.00^{\mathrm{a}}$ & $0.20 \pm 0.02^{\mathrm{b}}$ & $0.15 \pm 0.04^{\mathrm{ab}}$ \\
\hline Insulin-like $\left(\mathrm{mU} \mathrm{l}^{-1}\right)$ & $59.53 \pm 3.52$ & $61.53 \pm 2.83$ & $58.22 \pm 0.86$ & $67.75 \pm 1.28$ & $58.17 \pm 1.77$ & $60.97 \pm 3.38$ \\
\hline $\mathrm{CHH}\left(\mathrm{mU} \mathrm{l}^{-1}\right)$ & $128.92 \pm 6.08^{\mathrm{a}}$ & $172.80 \pm 5.81^{\mathrm{bc}}$ & $202.95 \pm 4.45^{\mathrm{c}}$ & $148.73 \pm 5.64^{\mathrm{ab}}$ & $141.48 \pm 6.09^{\mathrm{ab}}$ & $117.05 \pm 6.95^{\circ}$ \\
\hline
\end{tabular}

Data are presented as the means \pm SEM of three replicates $(n=3)$. Means in each line with different superscript letters are significantly different $(P<0.05)$. $\mathrm{CHH}$ : crustacean hyperglycemic hormone.
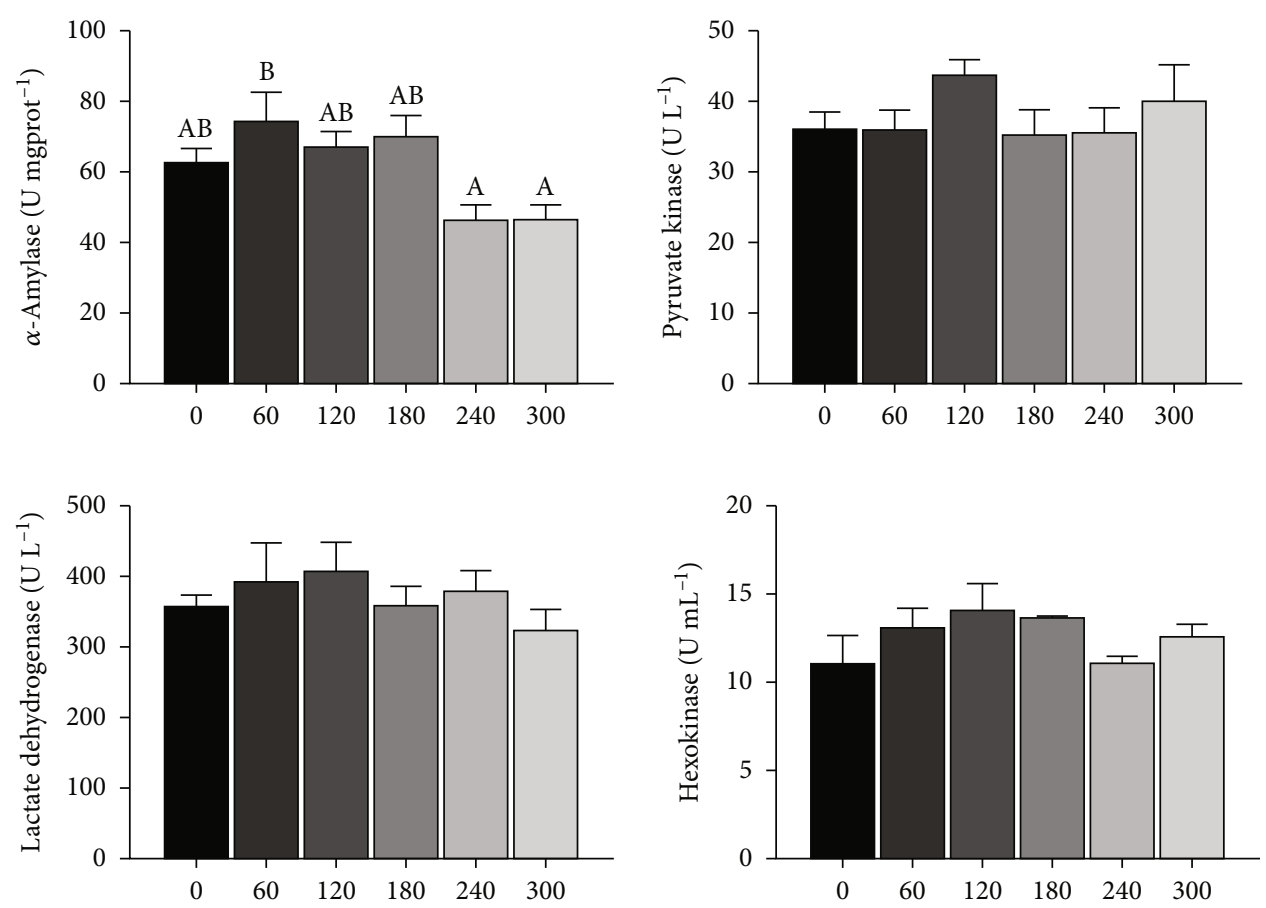

FIGURE 2: Effects of dietary carbohydrate levels on alpha-amylase activity in hepatopancreas and serum enzyme activities related to carbohydrate metabolism in Portunus trituberculatus. Values are expressed as the means of three replicates. Means in each bar with different superscript letters are significantly different $(P<0.05)$.
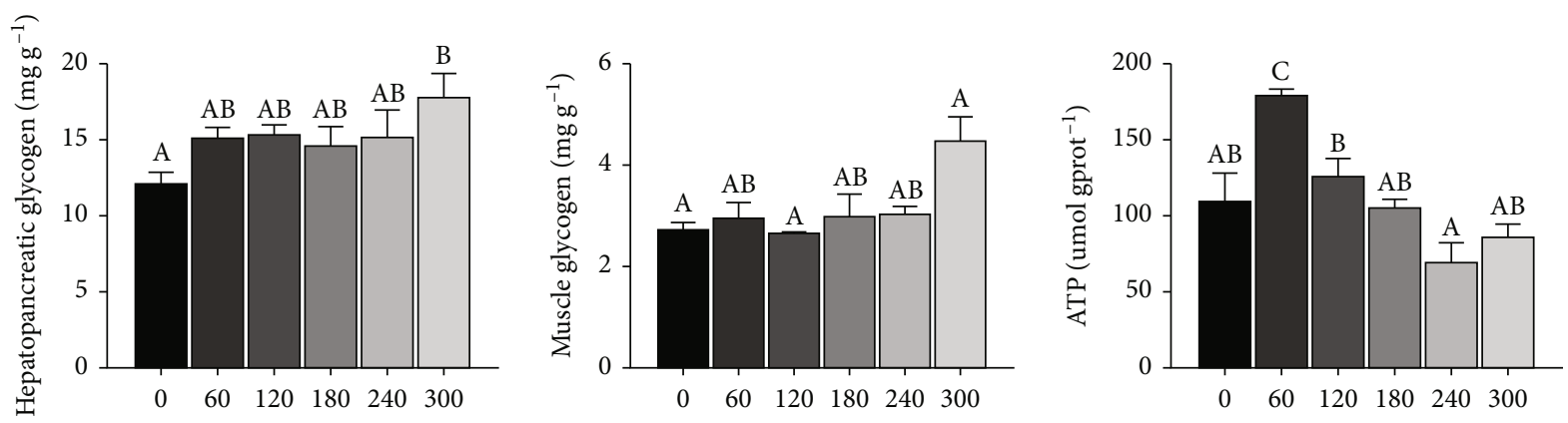

FIGURE 3: Effects of dietary carbohydrate levels on the glycogen contents in tissue and ATP in hepatopancreas for Portunus trituberculatus. Values are expressed as the means of three replicates. Means in each bar with different superscript letters are significantly different $(P<0.05)$. 

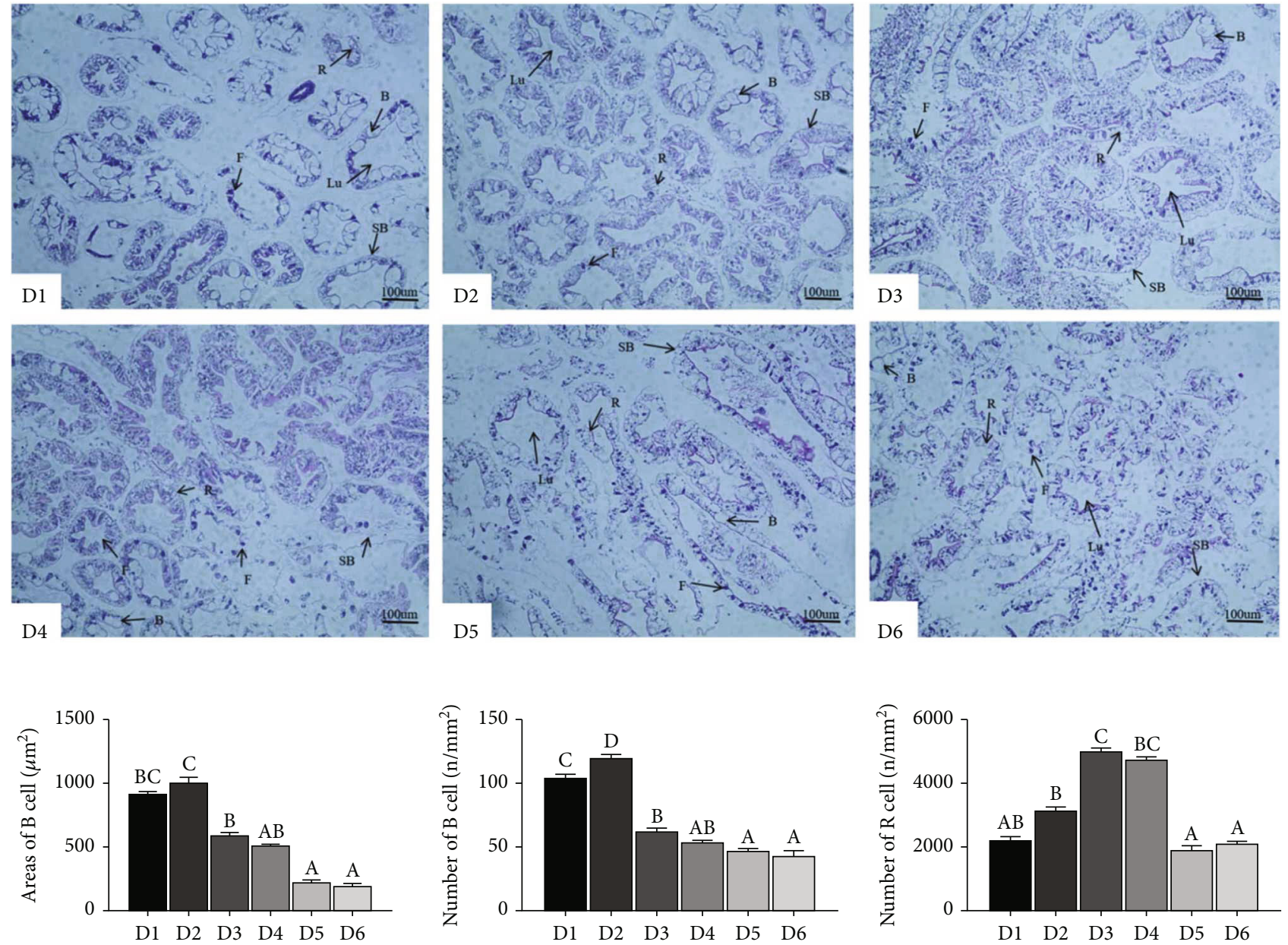

FIgURE 4: Effects of different dietary carbohydrate levels on hepatopancreas histological structure of Portunus trituberculatus. R: $\mathrm{R}$ (restzellen) cell; B: B (blasenzellen) cell; F: F (fibrous) cell; Lu: lumen structure; SB: striated border. Areas of B cell, number of B cell, and number of R cell are calculated. D1: $0.0 \mathrm{~g} \mathrm{~kg}^{-1}$ carbohydrate level; D2: $60.0 \mathrm{~g} \mathrm{~kg}^{-1}$ carbohydrate level; D3: $120.0 \mathrm{~g} \mathrm{~kg}^{-1}$ carbohydrate level; D4: $180.0 \mathrm{~g} \mathrm{~kg}^{-1}$ carbohydrate level; D5: $240.0 \mathrm{~g} \mathrm{~kg}^{-1}$ carbohydrate level; D6: $300.0 \mathrm{~g} \mathrm{~kg}^{-1}$ carbohydrate level. Values were expressed as the means of three replicates. Means in each bar with different superscript letters were significantly different $(P<0.05)$.

significantly reduced with carbohydrate levels increased $(P<0.05)$. Conversely, the number of $\mathrm{R}$ cell was significantly increased, but a drop appeared in 240.0 and $300.0 \mathrm{~g} \mathrm{~kg}^{-1}$ carbohydrate levels $(P<0.05)$.

3.6. Relative Expression of Genes Related to Glucose and Lipid Metabolism in Hepatopancreas. The expression levels of genes involved in glycolysis and gluconeogenesis are presented in Figure 5. The expressions of $p k$, fbpase, and pepck were significantly upregulated in crabs with the increase of carbohydrate levels $(P<0.05)$; however, the expressions of $h k$ and g6pase were significantly downregulated with dietary carbohydrate levels increasing from 0.0 to $60.0 \mathrm{~g} \mathrm{~kg}^{-1}$, and crabs fed with the $0.0 \mathrm{~g} \mathrm{~kg}^{-1}$ carbohydrate diet had higher expression levels of $h k$ and g6pase than those fed with the other diets $(P<0.05)$. Crabs fed with the 60.0 and $120.0 \mathrm{~g} \mathrm{~kg}^{-1}$ carbohydrate diets exhibited lower expression level of $g k$ than those fed with the 0.0 and $240.0 \mathrm{~g} \mathrm{~kg}^{-1}$ carbohydrate diets $(P<0.05)$.
The expression levels of genes related to glucose transport and glycogen synthesis in hepatopancreas of $P$. trituberculatus fed with dietary carbohydrate levels are shown in Figure 6. The expression level of glut 2 was not significantly influenced by dietary carbohydrate levels $(P>0.05)$; however, crabs fed with $60.0 \mathrm{~g} \mathrm{~kg}^{-1}$ carbohydrate diet had the lowest expression level of glut 1 and $g s k$ among all treatments $(P<0.05)$.

The expression levels of genes related to glucose and lipid metabolism are presented in Figure 7. The expression levels of srebp1 and cpt1 significantly upregulated with increase of dietary carbohydrate levels $(P<0.05)$; however, crabs fed with the $0.0,240.0$, and $300.0 \mathrm{~g} \mathrm{~kg}^{-1}$ carbohydrate diets exhibited higher expression levels of $c p t 2$ and acc than those fed with the $60.0,120.0$, and $180.0 \mathrm{~g} \mathrm{~kg}^{-1}$ carbohydrate diets $(P<0.05)$. Meanwhile, the expression levels of fas, $6 p g d$, and $g 6 p d$ were significantly downregulated with dietary carbohydrate levels increasing $(P<0.05)$.

The expression levels of genes related to insulin-like pathway are showed in. Crabs fed with $60.0 \mathrm{~g} \mathrm{~kg}^{-1}$ carbohydrate 


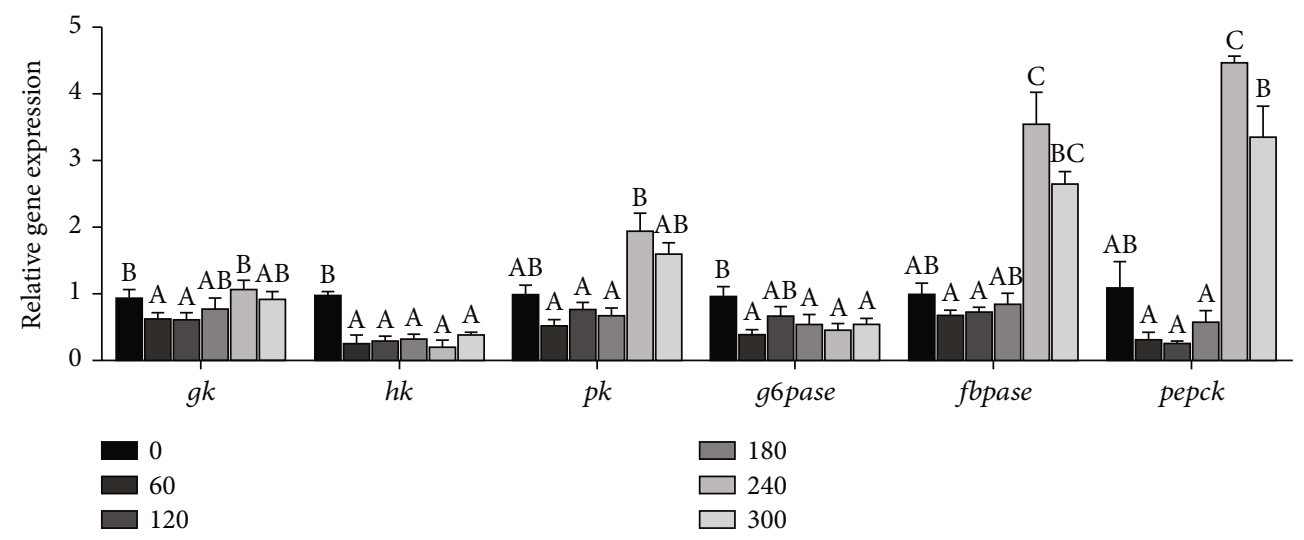

FIgURE 5: The expression levels of genes related to glycolysis and gluconeogenesis in the hepatopancreas of Portunus trituberculatus fed with dietary carbohydrate levels. Values are expressed as the means of three replicates. Means in each bar with different superscript letters are significantly different $(P<0.05) . g k$ : glucokinase; $p k$ : pyruvate kinase; $h k$ : hexokinase; $g 6 p a s e$ : glucose-6-phosphatase; fbpase: fructose-1,6bisphosphatase; pepck: phosphoenolpyruvate carboxykinase.

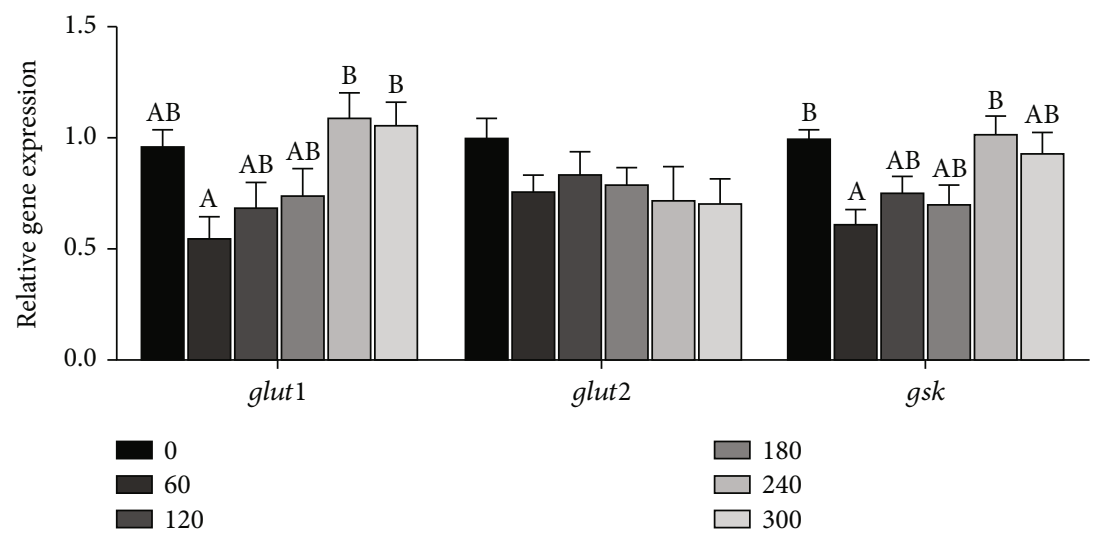

Figure 6: The expression levels of genes related to glucose transport and glycogen synthesis in the hepatopancreas of Portunus trituberculatus fed with dietary carbohydrate levels. Values are expressed as the means of three replicates. Means in each bar with different superscript letters are significantly different $(P<0.05)$. glut1: glucose transporter 1; glut2: glucose transporter 2; gsk: glycogen synthase kinase.

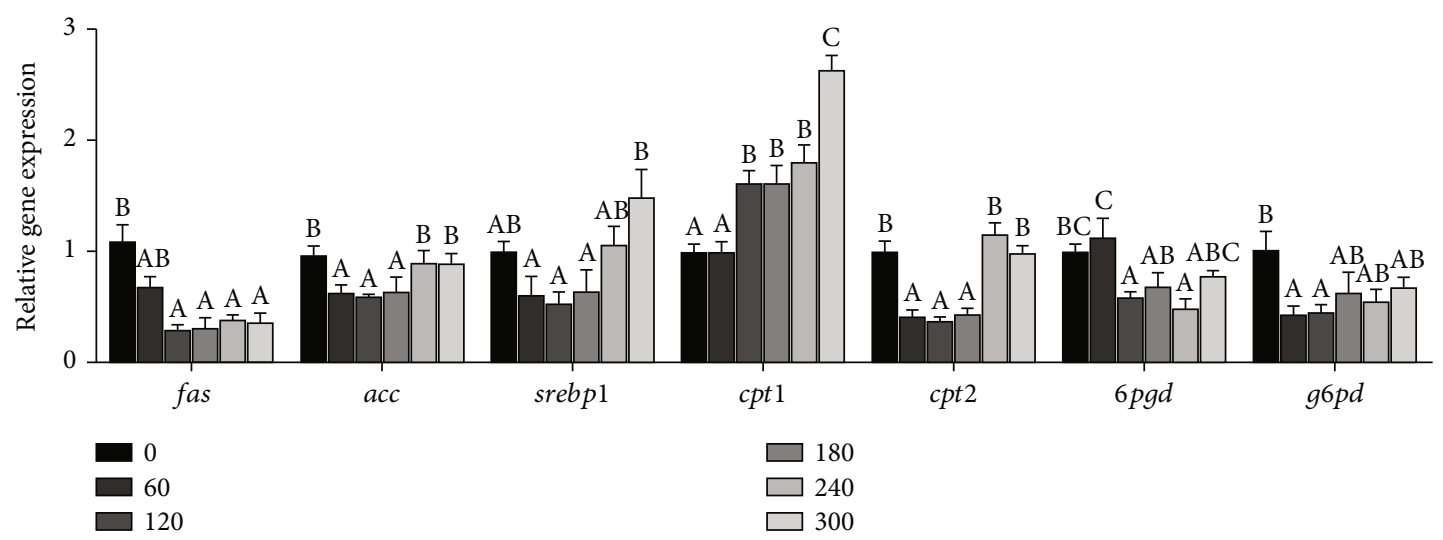

Figure 7: The expression levels of genes related to glucose and lipid metabolism in the hepatopancreas of Portunus trituberculatus fed with dietary carbohydrate levels. Values are expressed as the means of three replicates. Means in each bar with different superscript letters are significantly different $(P<0.05)$. fas: fatty acid synthase; acc: acetyl-CoA carboxylase; srebp1: sterol regulator element-binding protein 1; cpt1: carnitine palmitoyltransferase 1; cpt2: carnitine palmitoyltransferase 2; g6pd: glucose 6-phosphate dehydrogenase; 6pgd: 6phosphogluconate dehydrogenase. 


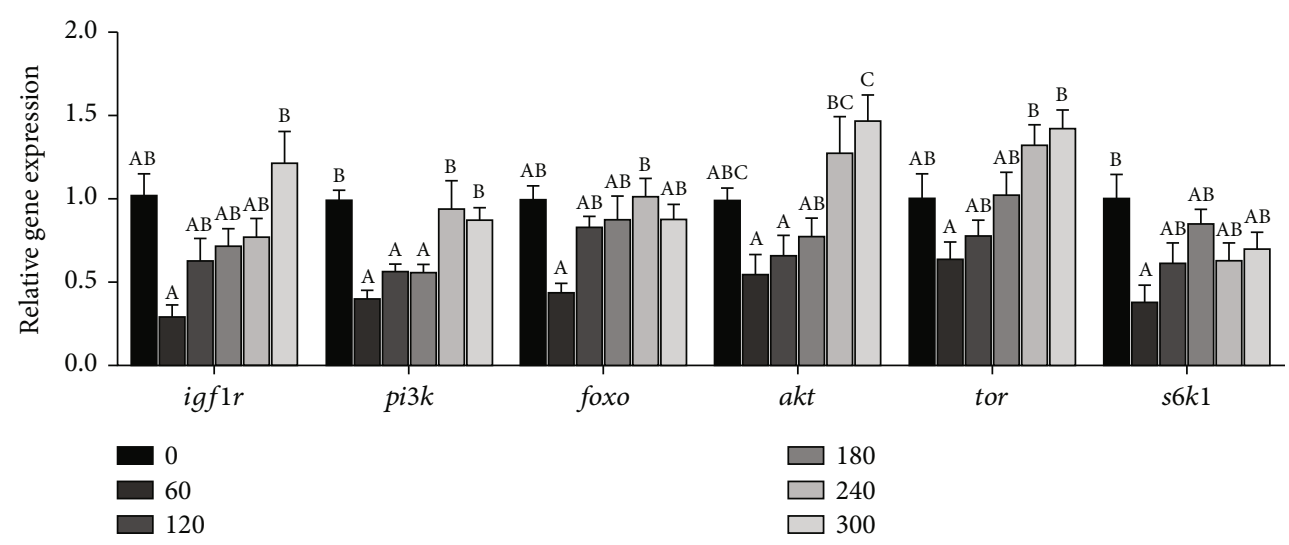

FIgURe 8: The expression levels of genes related to insulin-like metabolism in the hepatopancreas of Portunus trituberculatus fed with dietary carbohydrate levels. Values are expressed as the means of three replicates. Means in each bar with different superscript letters are significantly different $(P<0.05)$. igflr: insulin-like growth factor 1 receptor; pi3k: phosphoinositide-3-kinase; foxo: forkhead-box class O; akt: protein kinases B; tor: target of rapamycin; $56 \mathrm{kl}$ : ribosomal protein $\mathrm{S} 6$ kinase1.

diet had the lowest expression levels of igflr, pi3k, foxo, ak Figure $8 t$, tor, and $s 6 k 1$ among all treatments $(P<0.05)$, and the highest expression levels of igflr, akt, and tor were observed at crabs fed with $300.0 \mathrm{~g} \mathrm{~kg}^{-1}$ carbohydrate diet among all treatments $(P<0.05)$.

\subsection{Heat Map Visualisation Analysis of Glucose and Lipid} Metabolism and Insulin-Like Metabolism. Heat map visualisation was conducted to present the macroscopic effects of dietary carbohydrate levels on glucose, lipid, and insulinlike metabolism of swimming crab (Figure 9). All data were normalized with red color representing higher values and blue color representing lower values. The results clearly indicated that lower values of activities and expression levels of genes resolved into glucose, lipid, and insulin-like metabolism were observed in crabs fed with the diets containing 60.0 and $120.0 \mathrm{~g} \mathrm{~kg}^{-1}$ carbohydrate.

\section{Discussion}

In the present study, based on broken-line and second-order polynomial regression analysis between PWG against dietary carbohydrate levels, the optimal actual carbohydrate level was estimated to be $87.8-98.4 \mathrm{~g} \mathrm{~kg}^{-1}$ for juvenile Portunus trituberculatus. Meanwhile, dietary $180.0 \mathrm{~g} \mathrm{~kg}^{-1}$ carbohydrate level did not lead to growth inhibition, and the PWG and SGR significantly decreased with the further increase of dietary carbohydrate levels. In recent years, due to the high price of protein sources such as fish meal, aquafeed enterprises try to reduce feed cost from the perspective of reducing feed protein content and increasing energy level, while carbohydrate is the cheapest energy source. For this purpose, many research results showed that about 180.0$200.0 \mathrm{~g} \mathrm{~kg}^{-1}$ of the carbohydrate content in the feed formula is suitable for crustaceans, such as Pacific white shrimp (Litopenaeus vannamei) [6,37], Penaeus monodon (Fabricius) [13], mud crab (Scylla serrata) [38], and Chinese mitten crab (Eriocheir sinensis) [15], without significantly reducing the growth efficiency. This was similar to our research results.
In the present study, although the energy of each diet in this experiment is not equal, the energy level of each feed in this experiment can meet the requirements of normal growth of $P$. trituberculatus from the perspective of growth performance. The MI of crabs fed with the 240.0 and $300.0 \mathrm{~g} \mathrm{~kg}^{-1}$ carbohydrate levels was significantly longer than other carbohydrate diets. It was well known that crustacean growth depends on the molting process [39]. However, high carbohydrate aquafeed affected the health of crabs [5] and extended its molting cycle, which may be one of the main reasons for the poor growth performance of crabs fed with the 240.0 and $300.0 \mathrm{~g} \mathrm{~kg}^{-1}$ carbohydrate levels.

Dietary excessive carbohydrate levels can lead to the accumulation of lipids in aquatic animals $[6,40,41]$. In the present study, crabs fed with the diet without carbohydrate supplementation showed the lower lipid content in whole body than those fed with the other diets; however, lipid content in muscle and hepatopancreas was not significantly influenced by dietary carbohydrate levels. Many studies demonstrated that excessive glucose can synthesize more glycogen which is first consumed when the body supplies energy $[6,18,41]$. In this study, the glycogen content in muscle and hepatopancreas significantly increased with increase of dietary carbohydrate levels. However, excessive glycogen accumulation can cause lipid deposition and tissue damage, especially in hepatopancreas [10, 42]. It can be seen from the light microscope section in hepatopancreas that the number of $\mathrm{R}$ cell, which is a primary place in lipid deposition and storage $[43,44]$, significantly increased with the dietary carbohydrate levels increasing from 0.0 to $180.0 \mathrm{~g} \mathrm{~kg}^{-1}$; the decrease of $\mathrm{R}$ cells at crabs fed with the 240.0 and $300.0 \mathrm{~g} \mathrm{~kg}^{-1}$ carbohydrate diets may be caused by the severe lysis of hepatopancreatic tubules and the inability. The results also indicated that dietary excessive carbohydrate levels will lyse hepatopancreatic tubules. Meanwhile, in the present study, dietary excessive cellulose might also lead to more vacuoles in the hepatopancreas, because crabs fed with the 0.0 and $60.0 \mathrm{~g} \mathrm{~kg}^{-1}$ carbohydrate diets had more B cells than those fed with the other diets. 


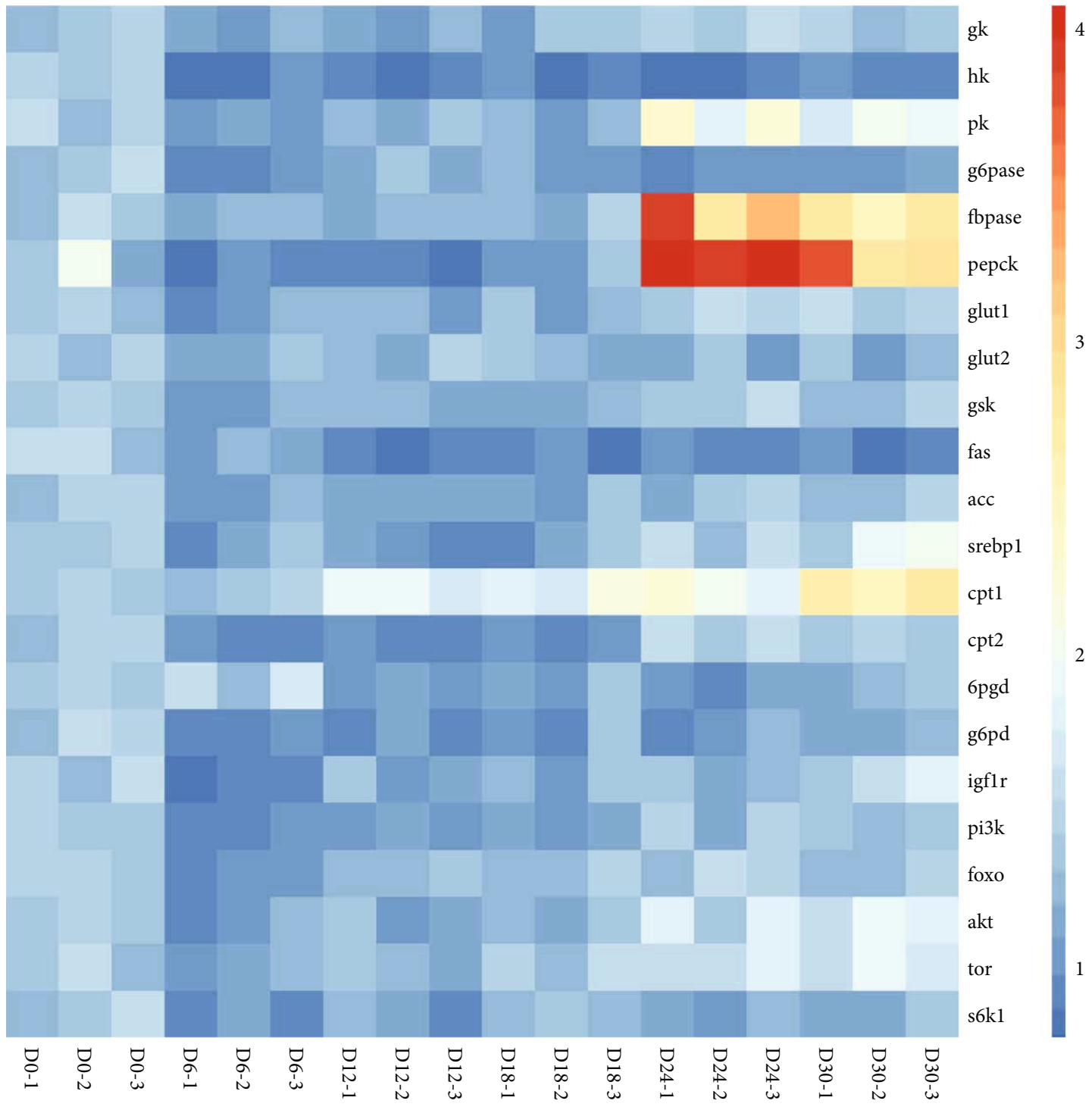

FIGURE 9: Heat map analysis of gene expressions related to glucose and lipid metabolism, glucose transport, and insulin-like metabolism in the hepatopancreas of Portunus trituberculatus fed with dietary carbohydrate levels. From dark blue to positive red, it represents the process of gradual increase of gene expression. D0: $0.0 \mathrm{~g} \mathrm{~kg}^{-1}$ carbohydrate level; D6: $60.0 \mathrm{~g} \mathrm{~kg}^{-1}$ carbohydrate level; D12: $120.0 \mathrm{~g} \mathrm{~kg}^{-1}$ carbohydrate level; D18: $180.0 \mathrm{~g} \mathrm{~kg}^{-1}$ carbohydrate level; D24: $240.0 \mathrm{~g} \mathrm{~kg}^{-1}$ carbohydrate level; D30: $300.0 \mathrm{~g} \mathrm{~kg}^{-1}$ carbohydrate level.

Glycogen in tissue is synthesized from glucose in serum or hemolymph. In this study, crabs fed with the diet without carbohydrate supplementation had the lowest glucose content in hemolymph. Starch needs to be digested and broken down to glucose by alpha-amylase before entering the animal body. Alpha-amylase is the most important enzyme among many enzymes that digest carbohydrates [45]. In the present study, crabs fed with the $60.0 \mathrm{~g} \mathrm{~kg}^{-1}$ carbohydrate diet had higher alpha-amylase content in hepatopancreas than those fed with the 240.0 and $300.0 \mathrm{~g} \mathrm{~kg}^{-1}$ carbohydrate diets. Pyruvate can realize the mutual conversion of glucose, lipids, and amino acids in the body through the acetyl CoA and tricarboxylic acid cycle which plays an important pivotal role in the metabolic connection of the three major nutrients [1]. Pyruvate and lactic acid are converted into each other under the action of lactate dehydrogenase [46, 47]. Hexoki- nase $(\mathrm{HK})$ and pyruvate kinase $(\mathrm{PK})$ are the key enzymes of glycolysis pathway; when the body consumes more energy and the content of ATP in the cell decreases, related glycolytic enzymes are activated to accelerate the decomposition of glucose for energy; when the ATP storage in the cell is abundant, the glycolytic activity is correspondingly weakened. In the present study, high carbohydrate groups had higher pyruvate content and low carbohydrate levels led to lower lactic acid content. The lactate dehydrogenase and $\mathrm{PK}$ and $\mathrm{HK}$ activities in hepatopancreas were not significantly influenced by dietary carbohydrate levels. Many studies in fish indicated that dietary carbohydrate level has no significant effect on the activity of HK enzymes [24, 48-50].

In addition to carbohydrate metabolizing enzymes, hormones are also a key factor in regulating glucose metabolism. In animals, insulin and glucagon are the key hormones 
that regulate glucose metabolism [51]. For decades, it has been always believed that the regulation of blood glucose was controlled by only two of them; however, with the gradual deepening study, it has been found that the theory could not explain the precise regulation of blood glucose homeostasis, and other regulatory hormones such as growth hormone and leptin have been identified $[52,53]$. However, so far, there are only two main hormones, insulin-like peptides and hyperglycemia hormones, participating in the regulation of glucose [54]. Similar to insulin function, injection of insulin-like peptide recombinant protein has the function of lowering hemolymph glucose in Chinese mitten crab, but the specific mechanism is unknown [54]. Crustacean hyperglycemic hormone $(\mathrm{CHH})$ is the only known hemolymph glucose-regulating hormone, and type I CHH has the function of increasing hemolymph glucose [54]. In this study, the insulin-like peptide content in hemolymph had no significant difference among all treatments. The $\mathrm{CHH}$ content in hemolymph significantly increased with dietary carbohydrate levels increasing from 0.0 to $120.0 \mathrm{~g} \mathrm{~kg}^{-1}$ and then significantly decreased with further increase of dietary carbohydrate level. The $\mathrm{CHH}$ content is similar to growth trend because $\mathrm{CHH}$ family, except type I $\mathrm{CHH}$, has the effect of regulating the swelling of the outer epidermis to assist in molting and participating in the growth of the body after molting [55].

The main nutrient metabolism organ of crustaceans is hepatopancreas, which plays an indispensable role in crustaceans [56]. Glucose derived from dietary carbohydrate is first absorbed by the hepatopancreas epithelial cells of crustaceans and then transported throughout the organism by hemolymph [4]. However, glucose cannot pass through the lipid bilayer of the hemolymph membrane; it must enter the cell through the glucose transporter family (GLUTs) on the cell membrane. GLUT1 is a highly conserved protein in evolution, is responsible for the uptake of glucose into cells, and is the first glucose transporter family to be cloned [57]. GLUT2 plays a key role in glucose signaling pathway for insulin secretion and biosynthesis in cells [58]. In the present study, the expression of glut 1 significantly increased with the increase of dietary carbohydrate levels, but the glut2 expression in hepatopancreas was not significantly increased by dietary carbohydrate levels. After glucose enters the body, glycogen synthase (GS) plays a key role in the process of glycogen synthesis and glycogen synthase kinase (GSK) regulates the conversion of glucose to glycogen through phosphorylation of glycogen synthase [59]. Thus, dietary higher carbohydrate levels enhanced the expressions of $g s k$ in hepatopancreas. In addition to synthesizing glycogen, glucose can also be decomposed into pyruvate under the glycolytic pathway. The three enzymes $h k, g k$, and $p k$ are the key enzymes in the glycolysis process, and their simultaneous expression promotes the occurrence of glycolysis. Many studies indicated that high carbohydrate levels can upregulate the expression of glycolysis-related genes [54, 60,61], which is consistent with the results of this experiment. However, $\mathrm{HK}$ and GK are isoenzymes, and $\mathrm{HK}$ has poor specificity. Some study indicated that the dietary carbohydrate level had no significant effect on the expression of $h k[62,63]$. The key enzymes that regulate the gluconeogenesis pathway are G6Pase, FBPase, and PEPCK. In this study, the expression of key gluconeogenesis enzyme genes, such as fbpase and pepck, significantly increased with the increase of dietary carbohydrate levels. Some studies in fish showed that excessive carbohydrate levels can inhibit the gluconeogenesis pathway while promoting glycolysis [61]. Unlike fish, crabs seem to be able to upregulate the expression of key genes such as glycolysis and gluconeogenesis with increase of dietary carbohydrate levels.

The process of lipid accumulation caused by increased carbohydrate levels will inevitably cause changes in the expression of genes related to fatty acid synthesis pathways. Acetyl-CoA carboxylase (ACC) is a cytoplasmic enzyme that can convert acetyl-CoA into malonyl-CoA, which is an important substrate involved in fatty acid biosynthesis [64]. Fatty acid synthase (FAS) is an important ratelimiting enzyme that catalyzes the de novo synthesis of fatty acids and converts malonyl-CoA to saturated fatty acids [65]. Sterol regulatory element-binding protein 1 (SREBP 1) is a transcription factor-regulating fatty acid synthesis [66]. 6-Phosphogluconate dehydrogenase (6PGD) and glucose-6-phosphate dehydrogenase (G6PD) are key enzymes that regulate fatty acid biosynthesis [67]. Moreover, G6PD can also promote the occurrence of the pentose phosphate pathway, which is considered to be the main pathway of the molting interphase in decapod [68]. Fatty acids are decomposed in the form of $\beta$-oxidation and enter the mitochondria with the assistance of carnitine palmitoyltransferase (CPT) for oxidation and energy supply. In this study, the expressions of $a c c$, srebp1, and $g 6 p d$ significantly upregulated with dietary carbohydrate levels increasing; however, excessive carbohydrate levels upregulated mRNA levels of $c p t 1$ and $c p t 2$.

The insulin-like growth factor (IGF) polypeptides are closely related to the metabolism of carbohydrates, and they can accelerate the synthesis of glycogen to reduce glucose content in the blood. Insulin-like peptides have a function similar to that of insulin in vertebrates in American lobsters which can promote glycogen synthesis [69, 70]. Gutiérrez et al. [71] found that IGF may be involved in the regulation carbohydrate metabolism of Pacific white shrimp. Insulinlike peptides and IGF belong to the same polypeptide family. These studies showed that high carbohydrate can activate the insulin/IGF pathway. In this study, with the increase in dietary carbohydrate levels, the expression of insulin-like growth factor 1 receptor (igflr) significantly increased; meanwhile, the expression of genes such as phosphoinositide-3kinase (pi3k), forkhead-box class $\mathrm{O}$ (foxo), protein kinases $\mathrm{B}$ (akt), target of rapamycin (tor), and ribosomal protein S6 kinase1 ( $s 6 k 1)$ significantly upregulated with increase of dietary carbohydrate levels. The results indicated that after the insulin/IGF pathway was activated, the signal may transmit from igflr to the PI3K/AKT signaling pathway, which in turn stimulated foxo and tor, and the activation of the tor signaling pathway affected the expression of $s 6 k 1$. But the specific mechanism has yet to be verified.

In conclusion, the results of present study indicated that the optimal actual carbohydrate level was estimated to be $87.8-98.4 \mathrm{~g} \mathrm{~kg}^{-1}$. The accumulation of glycogen in muscle 
and hepatopancreas was positively correlated with dietary carbohydrate levels. However, excessive glycogen content will lyse the hepatopancreas tissue and lose its complete shape. Dietary carbohydrate levels could upregulate the expression of genes related to glucose and lipid metabolism and activate the insulin/IGF signaling pathway.

\section{Data Availability}

The data used to support the findings of this study are included within the article.

\section{Conflicts of Interest}

The authors declare that they have no known competing financial interests or personal relationships that could have appeared to influence the work reported in this paper.

\section{Acknowledgments}

This research was supported by the National Natural Science Foundation of China (32072987), the China Agriculture Research System of MOF and MARA (CARS-48), the National Key R\&D Program of China (2018YFD0900400), the Key Research Program of Zhejiang Province of China (2018C02037), and the K. C. Wong Magna Fund in Ningbo University.

\section{References}

[1] National Research Council (NRC), Nutrient Requirements of Fish and Shrimp, National Academies Press, Washington, DC, 2011.

[2] M. S. Azaza, N. Khiari, M. N. Dhraief, N. Aloui, M. M. Kraem, and A. Elfeki, "Growth performance, oxidative stress indices and hepatic carbohydrate metabolic enzymes activities of juvenile Nile tilapia, L., in response to dietary starch to protein ratios," Aquaculture Research, vol. 46, no. 1, pp. 14-27, 2015.

[3] G. I. Hemre and D. F. Deng, "Carbohydrates-chapter 4," in Dietary Nutrients Additives and Fish Health. Dietary Nutrients, Additives, and Fish Health, C. S. Lee, C. Lim, D. M. Gatlin, and C. D. Webster, Eds., pp. 95-110, Wiley Blackwell, 2015.

[4] X. Wang, E. Li, and L. Chen, "A review of carbohydrate nutrition and metabolism in crustaceans," North American Journal of Aquaculture, vol. 78, no. 2, pp. 178-187, 2016.

[5] X. F. Li, Y. Wang, W. B. Liu, G. Z. Jiang, and J. Zhu, "Effects of dietary carbohydrate/lipid ratios on growth performance, body composition and glucose metabolism of fingerling blunt snout breamMegalobrama amblycephala," Aquaculture Nutrition, vol. 19, no. 5, pp. 701-708, 2013.

[6] X. Wang, E. Li, J. G. Qin et al., "Growth, body composition, and ammonia tolerance of juvenile white shrimp Litopenaeus vannamei fed diets containing different carbohydrate levels at low salinity," Journal of Shellfish Research, vol. 33, no. 2, pp. 511-517, 2014.

[7] M. G. Stronk and P. Margaret, "The influence of pertussis vaccine on histamine sensitivity of rabbits and guinea pigs and on the blood sugar in rabbits and mice," Journal of Infectious Diseases, vol. 96, no. 2, pp. 152-161, 1955.

[8] E. Bauer, B. A. Williams, C. Voigt, R. Mosenthin, and W. A. Verstegen, "In vitro fermentation of various carbohydrate- rich feed ingredients combined with chyme from pigs," Archives of Animal Nutrition, vol. 64, no. 5, pp. 394-411, 2010.

[9] E. S. Beltrão, A. M. de Azevedo Silva, J. M. P. Filho, T. P. DiasSilva, and L. R. Bezerra, "Effect of different blend levels of spineless cactus and Mombasa hay as roughage on intake, digestibility, ingestive behavior, and performance of lambs," Tropical Animal Health and Production, vol. 53, no. 1, p. 140, 2021.

[10] B. S. Kamalam, F. Medale, and S. Panserat, "Utilisation of dietary carbohydrates in farmed fishes: new insights on influencing factors, biological limitations and future strategies," Aquaculture, vol. 467, pp. 3-27, 2017.

[11] S. Julnafe and F. M. Rex, "Comparative evaluation of different carbohydrates as dietary energy source for the mud crab Scylla serrata megalopa," AACL Bioflux, vol. 10, no. 4, pp. 797-804, 2017.

[12] A. S. Vinagre and R. Silva, "Effects of starvation on the carbohydrate and lipid metabolism in crabs previously maintained on a high protein or carbohydrate-rich diet," Comparative Biochemistry and Physiology Part A, vol. 102, no. 3, pp. 579-583, 1992.

[13] V. R. Alava and F. P. Pascual, "Carbohydrate requirements of Penaeus monodon (Fabricius) juveniles," Aquaculture, vol. 61, no. 3, pp. 211-217, 1987.

[14] C. Rosas, G. Cuzon, G. Gaxiola et al., "Influence of dietary carbohydrate on the metabolism of juvenile Litopenaeus stylirostris," Journal of Experimental Marine Biology and Ecology, vol. 249, no. 2, pp. 181-198, 2000.

[15] X. Jiang, Study on the suitable carbohydrate source, proteinenergy ratio and the digestibility and utilization rate of raw materials in Chinese mitten crab feed. [M.S. thesis], East China Normal University, 2013.

[16] L. F. Dong, T. Tong, Q. Zhang, and M. Z. Xu, "Effects of dietary carbohydrate level on growth performance, body composition and digestive enzyme activities of juvenile crab, Scylla paramamosain," Acta Hydrobiologica Sinica, vol. 43, no. 2, pp. 252-257, 2019.

[17] K. Deng, M. Pan, J. Liu et al., "Chronic stress of high dietary carbohydrate level causes inflammation and influences glucose transport through _SOCS3_ in Japanese flounder _Paralichthys olivaceus_,"Scientific Reports, vol. 8, no. 1, p. 7415, 2018.

[18] Q. Zhan, T. Han, X. Li et al., "Effects of dietary carbohydrate levels on growth, body composition, and gene expression of key enzymes involved in hepatopancreas metabolism in mud crab_Scylla paramamosain_," Aquaculture, vol. 529, p. $735638,2020$.

[19] A. Van Wormhoudt and P. Favrel, "Electrophoretic characterization of _Palaemon elegans_(crustacea, decapoda) $\alpha$ amylase system: Study of amylase polymorphism during the intermolt cycle," Comparative Biochemistry \& Physiology Part B, vol. 89, no. 2, pp. 201-207, 1988.

[20] E. Zeqiraj and F. Sicheri, "Getting a handle on glycogen synthase - Its interaction with glycogenin," Molecular Aspects of Medicine, vol. 46, pp. 63-69, 2015.

[21] C. Xu, E. C. Li, Y. Liu et al., "Effect of dietary lipid level on growth, lipid metabolism and health status of the Pacific white shrimp Litopenaeus vannamei at two salinities," Aquaculture Nutrition, vol. 24, no. 1, pp. 204-214, 2018.

[22] C. Xu, E. C. Li, S. Liu, Z. P. Huang, J. G. Qin, and L. Chen, "Effects of $\alpha$-lipoic acid on growth performance, body 
composition, antioxidant status and lipid catabolism of juvenile Chinese mitten crab Eriocheir sinensis fed different lipid percentage," Aquaculture, vol. 484, pp. 286-292, 2018.

[23] J. Zhao, X. Wen, S. Li, D. Zhu, and Y. Li, "Effects of dietary lipid levels on growth, feed utilization, body composition and antioxidants of juvenile mud crab Scylla paramamosain (Estampador)," Aquaculture, vol. 435, pp. 200-206, 2015.

[24] S. Pansert, C. Blin, and F. Medale, "Lack of significant longterm effect of dietary carbohdrates on hepatic glucose-6phosphatase expression in rainbow trout (Oncorhynchus mykiss)," Journal of Experimental Biology, vol. 11, no. 1, pp. 22-29, 2000.

[25] S. Pansert, E. Plagnes-Juana, and S. Kaushik, "Nutritional regulation and tissue specificity of gene expression for proteins involved in hepatic glucose metabolism in rainbow trout (Oncorhynchus mykiss)," The Journal of Experimental Biology, vol. 204, no. 13, pp. 2351-2360, 2001.

[26] L. C. R. Kucharski and R. Silva, "Effect of diet composition on the carbohydrate and lipid metabolism in an estuarine crab, Chasmagnathus granulata (Dana, 1851)," Comparative Biochemistry \& Physiology Part A, vol. 99, no. 1-2, pp. 215-218, 1991.

[27] W. Ye, X. Y. Tan, Y. D. Chen, and L. Zhi, "Effects of dietary protein to carbohydrate ratios on growth and body composition of juvenile yellow catfish, Pelteobagrus fulvidraco (Siluriformes, Bagridae, Pelteobagrus)," Aquaculture Nutrition, vol. 40, no. 12, pp. 1410-1418, 2009.

[28] M. Jin, Q. C. Zhou, W. Zhang, F. J. Xie, J. K. Shentu, and X. L. Huang, "Dietary protein requirements of the juvenile swimming crab, _Portunus trituberculatus_," Aquaculture, vol. 414-415, pp. 303-308, 2013.

[29] China Fishery Statistical Yearbook, Compiled by Fishery Bureau of China Agriculture Department, China Fishery Statistical Yearbook, 2019.

[30] M. N. Azra and M. Ikhwanuddin, "A review of maturation diets for mud crab genus Scylla broodstock: present research, problems and future perspective," Saudi Journal of Biological Sciences, vol. 23, no. 2, pp. 257-267, 2016.

[31] Y. W. Huo, M. Jin, P. P. Zhou, M. Li, K. S. Mai, and Q. C. Zhou, "Effects of dietary protein and lipid levels on growth, feed utilization and body composition of juvenile swimming crab, _Portunus trituberculatus_," Aquaculture, vol. 434, pp. 151158, 2014.

[32] S. Taher, N. Romano, A. Arshad, and M. Ebrahimi, “Assessing the feasibility of dietary soybean meal replacement for fishmeal to the swimming crab,_Portunus pelagicus_, juveniles," Aquaculture, vol. 469, pp. 88-94, 2017.

[33] AOAC, Official Methods of Analysis, Association of Official Analytical Chemists, Arlington, VA, 18th edition, 2006.

[34] M. Liu, Q. Feng, D. S. Francis, G. M. Turchini, C. Zeng, and $\mathrm{X}$. Wu, "Tamoxifen affects the histology and hepatopancreatic lipid metabolism of swimming crab Portunus trituberculatus," Aquatic Toxicology, vol. 213, article 105220, 2019.

[35] Y. Yuan, M. Jin, J. Xiong, and Q. C. Zhou, "Effects of dietary dosage forms of copper supplementation on growth, antioxidant capacity, innate immunity enzyme activities and gene expressions for juvenile Litopenaeus vannamei," Fish and Shellfish Immunology, vol. 84, pp. 1059-1067, 2019.

[36] K. J. Livak and T. D. Schmittgen, "Analysis of relative gene expression data using real-time quantitative PCR and the $2^{-\Delta \Delta \mathrm{CT}}$ method," Methods, vol. 25, no. 4, pp. 402-408, 2002.
[37] R. Guo, G. Y. Liang, Y. J. Liu, L. X. Tian, K. S. Mai, and X. Y. $\mathrm{Wu}$, "Effect of dietary carbohydrate and protein levels on growth performance and digestibility of Litopenaeus vannamei juvenile reared in brackish water," Journal of Fisheries, vol. 31, no. 3, pp. 355-360, 2007.

[38] P. H. Truong, A. J. Anderson, P. B. Mather, B. D. Paterson, and N. A. Richardson, "Effect of selected feed meals and starches on diet digestibility in the mud crab, Scylla serrata," Aquaculture Research, vol. 39, no. 16, pp. 1778-1786, 2008.

[39] A. C. Schmitt and E. A. Santos, "Lipid and carbohydrate metabolism of the intertidal crab Chasmagnathus granulata Dana, 1851 (Crustacea: Decapoda) during emersion," Comparative Biochemistry \& Physiology Part A, vol. 106, no. 2, pp. 329-336, 1993.

[40] L. V. Sick and J. W. Andrews, "The effect of selected dietary lipids, carbohydrates and proteins on the growth, survival and body composition of Penaeus duorarum 1," in Proceedings of the annual workshop-World Mariculture Society (Vol. 4, No. 1-4), pp. 263-276, Blackwell Publishing Ltd., Oxford, UK, 1973.

[41] V. L. Kallapur, Y. Ramamohanrao, and A. V. Narasubhai, "Glycolytic enzymes in the premolt field crab Paratelphusa hydrodromus (Milne-Edwards) (Crustacea)," Archives Internationales De Physiologie, vol. 91, no. 2, pp. 127-132, 1983.

[42] S. P. Zhang, J. F. Li, X. C. Wu, and W. J. Zhong, "Effects of different dietary lipid level on the growth, survival and immunerelating genes expression in Pacific white shrimp, Litopenaeus vannamei," Fish \& Shellfish Immunology, vol. 34, no. 5, pp. 1131-1138, 2013.

[43] E. Li, L. Chen, C. Zeng et al., "Comparison of digestive and antioxidant enzymes activities, haemolymph oxyhemocyanin contents and hepatopancreas histology of white shrimp, Litopenaeus vannamei, at various salinities," Aquaculture, vol. 274, no. 1, pp. 80-86, 2008.

[44] X. Xiao, D. Han, X. Zhu, Y. Yang, S. Xie, and Y. Huang, "Effect of dietary cornstarch levels on growth performance, enzyme activity and hepatopancreas histology of juvenile red swamp crayfish, _Procambarus clarkii_ (Girard)," Aquaculture, vol. 426-427, pp. 112-119, 2014.

[45] M. J. Macdonald, "Does glyceraldehyde enter pancreatic islet metabolism via both the triokinase and the glyceraldehyde phosphate dehydrogenase reactions? A study of these enzymes in islets," Archives of Biochemistry \& Biophysics, vol. 1, no. 270, pp. 15-22, 1989.

[46] Y. Hua, Utilization and mechanism of carbohydrate in diet of juvenile black sea bream Acanthopagrus schlegelii, [Ph.D thesis], Zhejiang University, 2017.

[47] C. P. Zhou, X. P. Ge, B. Liu, J. Xie, R. Chen, and M. Ren, "Effect of dietary carbohydrate level on growth performance, blood chemistry, hepatic enzyme activity, and growth hormone gene expression in Wuchang Bream (Megalobrama amblycephala) at two temperatures," Asian-Australasian Journal of Animal Sciences, vol. 2, no. 28, pp. 207-2014, 2015.

[48] P. Enes, S. Panseat, S. Kaushik, and A. Oliva-Teles, "Hepatic glucokinase and glucose-6-phosphatase responses to dietary glucose and starch in gilthead sea bream (Sparus aurata) juveniles reared at two temperatures," Comparative Biochemistry \& Physiology Part A, vol. 149, no. 1, pp. 80-86, 2008.

[49] P. Enes, S. Panseat, S. Kaushik, and A. Oliva-Teles, "Growth performance and metabolic utilization of diets with native and waxy maize starch by gilthead sea bream (Sparus aurata)," Aquaculture, vol. 274, no. 1, pp. 101-108, 2008. 
[50] I. S. Moreira, H. Peres, A. Couto, P. Enes, and A. Oliva-Teles, "Temperature and dietary carbohydrate level effects on performance and metabolic utilization of diets in European sea bass (Dicentrarchus labrax) juveniles," Aquaculture, vol. 274, no. 1, pp. 153-160, 2008.

[51] S. L. Aronoff, K. Berkowitz, B. Shreiner, and L. Want, "Glucose metabolism and regulation: beyond insulin and glucagon," Diabetes Spectrum, vol. 17, no. 3, pp. 183-190, 2004.

[52] N. Moller and J. O. Jorgensen, "Effects of growth hormone on glucose, lipid, and protein metabolism in human subjects," Endocrine Reviews, vol. 30, pp. 152-177, 2009.

[53] M. Ozata, I. C. Ozdemir, and J. Licinio, "Human leptin deficiency caused by a missense mutation: multiple endocrine defects, decreased sympathetic tone, and immune system dysfunction indicate new targets for leptin action, greater central than peripheral resistance to the effects of leptin, and spontaneous correction of leptin-mediated defects," Journal of Clinical Endocrinology \& Metabolism, vol. 84, no. 10, pp. 36863695, 1999.

[54] X. D. Wang, E. Li, and Z. X. Xu, "Molecular response of carbohydrate metabolism to dietary carbohydrate and acute low salinity stress in pacific white shrimp Litopenaeus vannamei," Turkish Journal of Fisheries \& Aquatic Sciences, vol. 17, pp. 153-169, 2017.

[55] H. Dircksen, L. K. Tesfai, C. Albus, and D. R. Nässel, "Ion transport peptide splice forms in central and peripheral neurons throughout postembryogenesis of Drosophila melanogaster," Journal of Comparative Neurology, vol. 509, no. 1, pp. 23-41, 2008.

[56] F. Cervellione, C. McGurk, T. Berger Eriksen, and W. van den Broeck, "Effect of starvation and refeeding on the hepatopancreas of whiteleg shrimp Penaeus vannamei (Boone) using computer-assisted image analysis," Journal of Fish Diseases, vol. 40, no. 11, pp. 1707-1715, 2017.

[57] M. Mueckler, C. Caruso, S. Baldwin et al., "Sequence and structure of a human glucose transporter," Science, vol. 229, no. 4717, pp. 941-945, 1985.

[58] M. T. Guillam, P. Dupraz, and B. Thorens, "Glucose uptake, utilization, and signaling in GLUT2-null islets," Diabetes, vol. 49, no. 9, pp. 1485-1491, 2000.

[59] Q. D. Zhang and L. Li, "Research progress of glycogen synthase kinase-3," Journal of HeZe Medical College, vol. 2, no. 19, pp. 85-86, 2007.

[60] X. F. Li, C. Xu, D. D. Zhang, G. Z. Jiang, and W. B. Liu, "Molecular characterization and expression analysis of glucokinase from herbivorous fish _Megalobrama amblycephala_ subjected to a glucose load after the adaption to dietary carbohydrate levels," Aquaculture, vol. 459, pp. 89-98, 2016.

[61] C. Xu, W. B. Li, D. D. Zhang, H. J. Shi, and X. F. Li, "Interactions between dietary carbohydrate and metformin: Implications on energy sensing, insulin signaling pathway, glycolipid metabolism and glucose tolerance in blunt snout bream _Megalobrama amblycephala_," Aquaculture, vol. 483, pp. 183-195, 2018.

[62] X. P. Ge, B. Liu, J. Xie, J. H. Yu, Y. K. Tang, and T. T. Wu, “The effect of different carbohydrate levels of dietary on the growth, plasma biochemical indices and hepatic pancreas carbohydrate metabolic enzymes in topmouth culter," Journal of Nanjing Agricultural University, vol. 30, no. 3, pp. 88-93, 2007.
[63] X. Z. Lin, Y. P. Luo, and X. J. Xie, "Effects of dietary carbohydrate levels on the activity of glycolytic enzymes and serum glucose concentrations in juvenile southern catfish after feeding," Acta Hydrobiologica Sinica, vol. 3, no. 30, pp. 304-310, 2006.

[64] Y. Qian, X. F. Li, D. D. Zhang, D. S. Cai, H. Y. Tian, and W. B. Liu, "Effects of dietary pantothenic acid on growth, intestinal function, anti-oxidative status and fatty acids synthesis of juvenile blunt snout bream Megalobrama amblycephala," PLoS One, vol. 10, no. 3, article e0119518, 2015.

[65] M. J. Walton and C. B. Cowey, "Intermediary metabolism," in Fish Nutrition, pp. 259-329, Academic Press, San Diego, 1989.

[66] M. Minghetti, M. J. Leaver, and D. R. Tocher, “Transcriptional control mechanisms of genes of lipid and fatty acid metabolism in the Atlantic salmon (Salmo salar L.) established cell line, SHK-1," Biochimica et Biophysica Acta, vol. 1811, no. 3, pp. 194-202, 2011.

[67] Q. Chen, Z. Luo, X. Liu, Y. F. Song, and Y. H. Zhao, "Effects of waterborne chronic copper exposure on hepatic lipid metabolism and metal-element composition in Synechogobius hasta," Archives of Environmental Contamination \& Toxicology, vol. 64, no. 2, pp. 301-315, 2013.

[68] M. A. Mcwhinnie and R. J. Kirchenberg, "Crayfish hepatopancreas metabolism and the intermoult cycle," Comparative Biochemistry \& Physiology, vol. 6, no. 2, pp. 1-128, 1962.

[69] B. Sanders, "Insulin-like peptides in the lobster Homarus americanus. I. Insulin immunoreactivity," General \& Comparative Endocrinology, vol. 50, pp. 366-373, 1983.

[70] B. Sanders, "Insulin-like peptides in the lobster_Homarus americanus_ II. Insulin-like biological activity," General \& Comparative Endocrinology, vol. 50, no. 3, pp. 374-377, 1983.

[71] A. Gutiérrez, J. Nieto, S. Pozo, L. Stern, and F. Schoofs, "Effect of insulin/IGF-I like peptides on glucose metabolism in the white shrimp Penaeus vannamei," General \& Comparative Endocrinology, vol. 153, no. 1-3, pp. 170-175, 2007.

[72] P. Sun, M. Jin, L. Jiao et al., "Effects of dietary lipid level on growth, fatty acid profiles, antioxidant capacity and expression of genes involved in lipid metabolism in juvenile swimming crab, Portunus trituberculatus," British Journal of Nutrition, vol. 2, no. 123, pp. 149-160, 2020. 